\title{
Alsiske Bøndergaarde.
}

\section{Af Museumsinspekter, Arkitekt H. Zangenberg.}

Som enhver gammel Bondegaard i Landet har den alsiske Gaard visse Træk fælles med vort Lands nvrige Bøndergaarde, og en Række Ejendommeligheder, som er krakteristiske for selve Egnen. Gaardene paa Als tiltrækker sig især Opmærksomheden ved det pregtige og fortrinlige Bindingsværk, der er anvendt ved Opførelsen af de gamle Bygninger, og de overordentlig brede Beboelseslænger, hvor Bredden er en Følge af Husenes to Rækker af Beboelsesrum paa hver sin Side af et Skillerum paa langs gennem Beboelsen. Den store Bredde, i Forbindelse med den høje Tagrejsning, giver Bygningerne et meget anseligt Ydre. Men det mest karakteristiske for Als er dog den store Uregelmæessighed i Gaardformerne, som præger Landsbyerne og giver dem en særlig ejendommelig og malerisk Karakter.

Trods denne Uregelmæssighed i Gaardenes Anlæg, hvorved Gaardene faar en stor indbyrdes Ulighed, er der dog et Træk, som er fælles for alle gamle alsiske Bondergaarde, idet $\mathrm{H}$ ovedh uset, det s a a k a l d t e "I n d h u s«, næsten overalt indeholder baade Beboelse, Sta!d og Lo, undertiden ogsaa Lade i én Bygning eller Længe, alt under ét Tag, men adskilt fra hinanden ved Skillerum paa tværs af Bygningens Længderetning. Denne Samling af Rum for baade Mennesker og Dyr, samt en Del af Afgrøden, i én lang Længe, er et af de Fællestræk, som knytter 
Als til den aldgamle danske Byggeskik, som man endnu indtil vor Tid har kunnet finde, ikke alene paa Naboøen Arø, med hvilken Als jo har været administrativt sammenknyttet, men ogsaa paa de fynske Øer Lyø, Taasinge og Strynø, samt paa Lolland-Falster og paa Bornholm. Denne Byggeskik, der sikkert har sin Rod i Oldtiden, og som i Middelalderen synes at have været almindelig udbredt overalt i Danmark, jævnsides med den tolængede Gaard, har vist ingen Stels her i Landet været fastholdt med saa stor Trofasthed gennem Tiderne som paa Als, og indtil for faa Aartier siden var den endnu ganske almindelig i de gamle alsiske Gaardes Indhuse, ja der fandtes endog Gaarde, som udelukkende bestod af en eneste Lange.

Om Hoved- og Grundformen for den alsisko Gaard har ældre Forfattere kun bragt sparsomme Oplysninger, hvilket er beklageligt, da de havde haft rig Lejlighed til at faa klaret dette Spørgsmaal ved et nøjere Studium af de den Gang eksisterende gamle Gaarde. De tre Forfattere, nemlig Direktoren for den højere Folkeskole i Rendsborg I. I. H. Lütgens, Professor R. Mejborg og Skoleinspektor P. Lauridsen, som alle især har beskæftiget sig med sonderjydske Gaarde, har for Als's Vedkommende indskrænket sig til en Omtale af Indhuset, og trods nogen Uenighed om Karakteren af og Aarsagen til den alsiske Gaards Uregelmæssigheder er alle de nævnte Forfattere enige om, at baade det lange og store Incihus, samt den uregelmæssige Placering af Gaardens øvrige Bygninger er det almindelige Kendetegn for den gamle alsiske Gaard, og deri har de utvivlsomt Ret, men naar baade Mejborg og Lauridsen er enige 
om, at Alsingerne først efter Begyndelsen af det 19. Aarh. med Forkærlighed har opført trelængede Gaarde, og Lauridsen tilføjer: »hvor næsten ethvert Minde om ældre Bygningsskikke eller lokal Oprindelighed er forsvunden«, da er dette sikkert ikke helt rigtigt.

I Byen Hagenbjerg fandtes der f. Eks. allerede i $17 \gamma 2$ trelængede Gaarde, og disse Gaarde er saaledes snarere en Byggeskik fra det 18. end fra det 19. Aarhundrede, og med Hensyn til Byggeskikken da har der ganske vist i Tiden omkring 1800 været Tilbøjelighed til at sammenbygge de fritliggende Længer og udskille visse af Hovedhusets Rum for at henlægge disse til særlige Smaabygninger, men man tor dog ikke tale om en saa fuldstændig Udslettelse af garimel Byggeskik, som Lauridsen gør det, tværtimod, mange af de gamle Træk blev bibeholdt og genfindes i de Indhuse, der blev opført i Begyndelsen af det 19. Aarh.

I Følge gamle Synsforretninger har den alsiske Gaard i Begyndelsen af det 18. Aarhundrede som Regel bestaaet af flere fritliggende Bygninger, der sammen med Indhuset omsluttede eller var lagt paa en mærkelig og ligesom tilfældig Maade ved eller om en Gaardsplads, hvorpaa Møddingen fandtes. En Gaajd har kunnet bestaa af én og helt op til 5 Længer, og deraf var altid den anseligste af dem det store Indhus, de øvrige var Udhusbygninger og enkelte "Korshuse«, som var Tilbygninger til Indhusene. En Overleverings-Forretning over Gammelgaard Gods i 1731 giver gode Oplysninger om Bønderbygningerne paa den Tid, og da man faar et meget godt Kendskab til den æeldre alsiske Gaard gennem 
denne Forretning, skal der et Øjeblik dvæles ved denne, der omfatter Godsets 84 Fæstegaarde og 103 Fæstebol- eller "K a a d n e r s t e d e r". Godsets Bøndergaarde var fordelte i Byerne Jestrup, Ertebjerg, Tandslet, Mommark og Asserballe, samt Ketting og Asserballe Skov, og af de 85 Gaarde var de 2 femlængede, 7 var firelængede, 37 trelængede og 38 tolængede og ençelig én var enlænget. Foruden disse Længer fandtes der ikke sjaldent i Gaardene en lille Trælade eller Hjelm, som i Overleveringsforretningens tyske Sprog kaldes "L u f t s c h e u n eж.

Til hver af Gaardene horte et Indhus, som var indrettet til Beboelse, Stald og Lade og var fra 14 til 20 Fag langt og 11-16 Alen bredt. Den enlængede Gaard, som laa i Asserballe Skov, var 19 Fag lang og 12 Alen bred, og Beboelsen bestod her af 4 Fag. Ellers kunde den gaa helt op til 11 Fag. Udhusene var Lader og Aftægtshuse, og disse sidste traadte undertiden i Stedet for Ladebygningerne, idet de ogsaa indeholdt Lader og Kostalde. Laderne kunde fra 4 Fags Længde og 7 Alens Bredde naa op til 20 Fag og 11 Alens Bredde, og Aftægtshusene varierede lige saa stærkt, nemlig fra 7 til 13 Al. i Bredden og fra 3-17 Fag i Længden, og heraf kunde Beboelsen indtage fra 2 til 8 Fag. Endvidere var Hjelmene fra 4-6 a 7 Fag lange og 7 til 10 Alen brede. Til omtrent Halvdelen af Gaardene hørte der en saadan Hjelm. Disse Hjelme, som vistnok kun kendes fra Als, synes at gaa helt tilbage til den første Halvdel af det 17. Aarhundrede, hvorfor der i Nutiden kun er meget faa tilbage. Denne store Afvekslen, saavel i Placering og Antallet af Bygninger, som i Størrelsen af selve Bygningerne, gør, at man faar det 
Indtryk, at saavel Lader som Aftægtshuse er senere Udvidelser til en oprindeligt mindre Gaard, og at de er opførte gennem Tiderne, eftersom udvidet Opdyrkning har fordret mere Husrum, og eftersom man har haft Raad og Lejlighed til at forøge Gaarden med flere Bygninger.

Om selve Husbygningsmaterialet faar man ved nævnte Overleveringsforretning den Oplysning, at Bindingsværkets "S t e n d e r« - (d. v. s. Stolper), staar paa Fodstykker, og at dette saavel som Vægtømmeret er af Eg. Bjælkerne er ligeledes af $\mathrm{Eg}-$ eller ogsaa Fyrretræ, Spærene er af Eg, Fyr, Elleog Asketræ og Væg g n e er gam le, klinede af Ler paa Vægstaver, endvidere er Tagene dækkede med Straa eller Rør. Hjelmene er beklædte med Ege-, Bøge-, Fyrre- og Ellebrædder.

Ligesom selve Gaardene, saaledes har de alsiske Landsbyer ogsaa været af en lidt egen Karakter, idet de synes især at have været anlagte som Terrænbyer langs de Veje, der førte gennem dem; og netop dette bidrager yderligere til at fremhæve det maleriske $i$ den alsiske Landsby. Paa Billedet, Fig. 1, der viser Byplanerne af de to sydalsiske Landsbyer Lambjerg og Klinting fra 1794 og 1795, ses tydeligt det uensartede ved den alsiske Gaard, samt Gaardenes Anbringelse langs Vejene, uden noget Forsøg paa at samle dem i en sluttet Landsby. Gaardanlægene i disse to Byer viser især, hvorledes den alsiske Gaard i tidligere Tider har bestaaet af fritliggende Længer, grupperet med det storre Indhus ved og om en Gaardsplads. Her er alle Arter af Gaarde repræsenterede, helt fra den enlængede Gaard, med paabygget kort Vinkelfløj, og Parallelgaarden op til den 
firelængede Gaard, og man ser, at det har været forholdsvis let at sammenbygge de forskellige Længer,
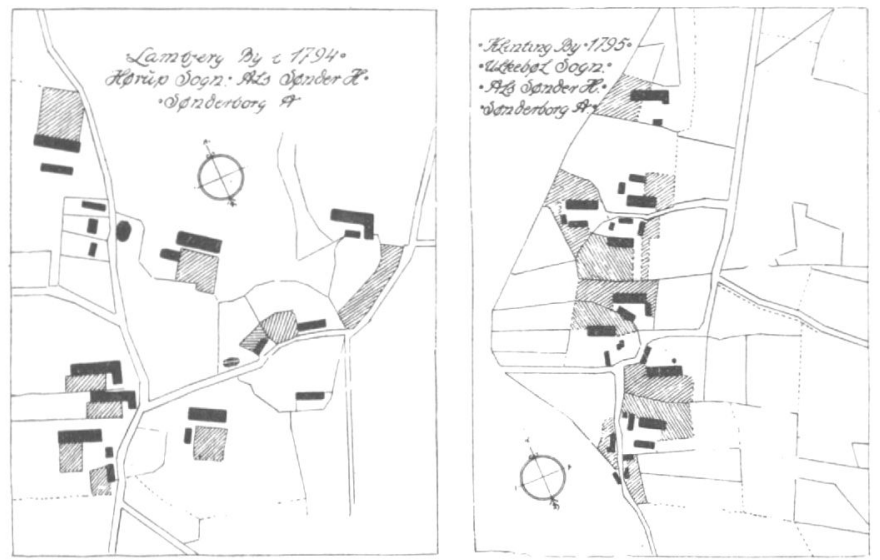

Fig. 1. Byerne Klinting og Lambjerg ved Udskiftningen. (Efter Kort $i$ Sonderborg Museum.)

saa at de tilsidist har dannet et sluttet og lukket Hele, og navnlig har det været en let Sag at frembringe trelængede Gaarde.

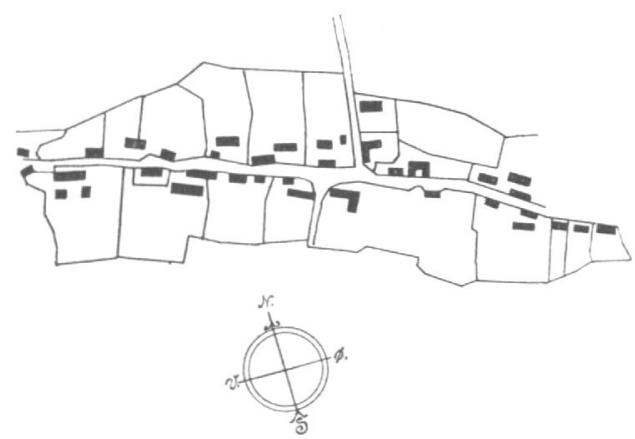

Fig.2. Byen Egen ved Udskiftningen. (Efter Danmarks Folkeminder Nr.31).

En anden Ting man ogsaa lægger Mærke til er den, at Bygningerne, i hvert Fald Indhusene, ligger solret, det vil sige med Gavlene i Øst og Vest, og det vil man finde saa at sige overalt paa Als. At man 
paa Als ogsaa har haft Byer, hvor den enlængede Gaardskarakter har været endog meget følelig i den sidste Fjerdedel af det 18. Aarhundrede, sesi af Fig. 2, Byplanen for Byen Egen, en af de midtalsiske Byer. Kun den trelængede Kro og et Par Vinkelsteder bry-

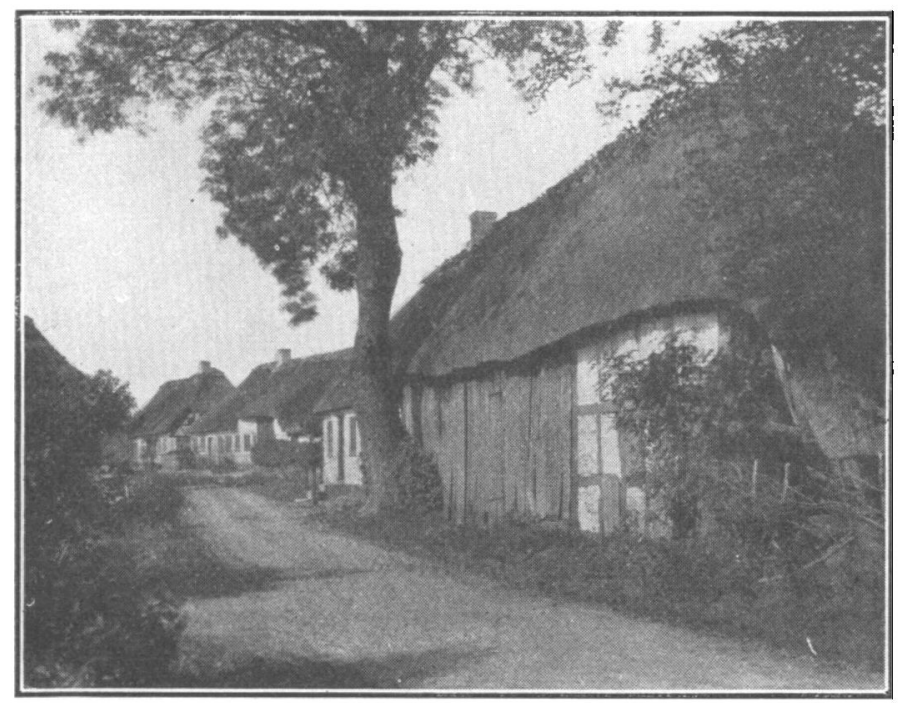

Fig. 3. Landsbyen Dyndved i Egen Sogn. (Forf. fot. 1929).

der Gaardkarakteren, og naar der nogle Steder findes flere Bygninger, er disse de sædvanlige vistnok senere byggede Aftægtshuse og Lader, som ikke bekræfter Professor Mejborgs Udtalelse om, at man paa Grund af Pladsmangel nodtes til at bygge i Vinkler, men snarere understreger, at man ved senere Forøgelser af Gaardens Bygninger har fulgt gammel Tradition og opfort enlængede Bygninger, hver til sit Brug, uden Tanke for at bygge Længerne sammen.

At man ogsaa har lagt Indhusene ud langs Landsbygaden vil man se paa Gadebilledet af Lands- 


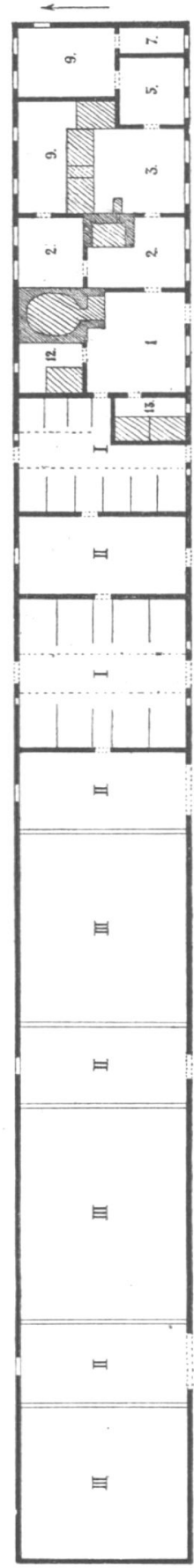

byen Dyndved i Egen Sogn, Fig. 3, men det er dog vistnok oftest Kaadके ner- eller Bolsstedet og (⿸丆口 Huset uden Jordbrug, der har faaet denne Beliggenhed. Iøvrigt giver Billedet en god Prove paa det smukke og maleriske Præg, som tidligere er omtalt, og som de alsiske Landsbyer oftest besidder, naar da ikke moderne Ombygninger har skaniniet Landsbybilledet.

At de alsiske Indhuse har været overordentlig lange og har kunnet indeholde alle de Rum, som var nodvendige for Gaardens Brug, ses af Fig. 4, der viser en Grundplan som Professor Mejborg maalte i Landsbyen Egen i 1887. Gaarden blev opsøgt i 1923, men da var den blevet væsentligt forkortet, idet flere af Laderummene var blevet. revet ned. Huset er fra det 18. Aarhundrede og er det længste enlængede Hus, som der er foretaget nogen Opmaaling af. Det var 117 Al. $\quad(73,2$ m.) langt og $13 \mathrm{Al}$. 
(8,16 m.) bredt. I Husets Østende findes Beboelsen med de to Rækker af Beboelsesrum, dernæst kommer Staldene, som Beboelsen staar i direkte For-

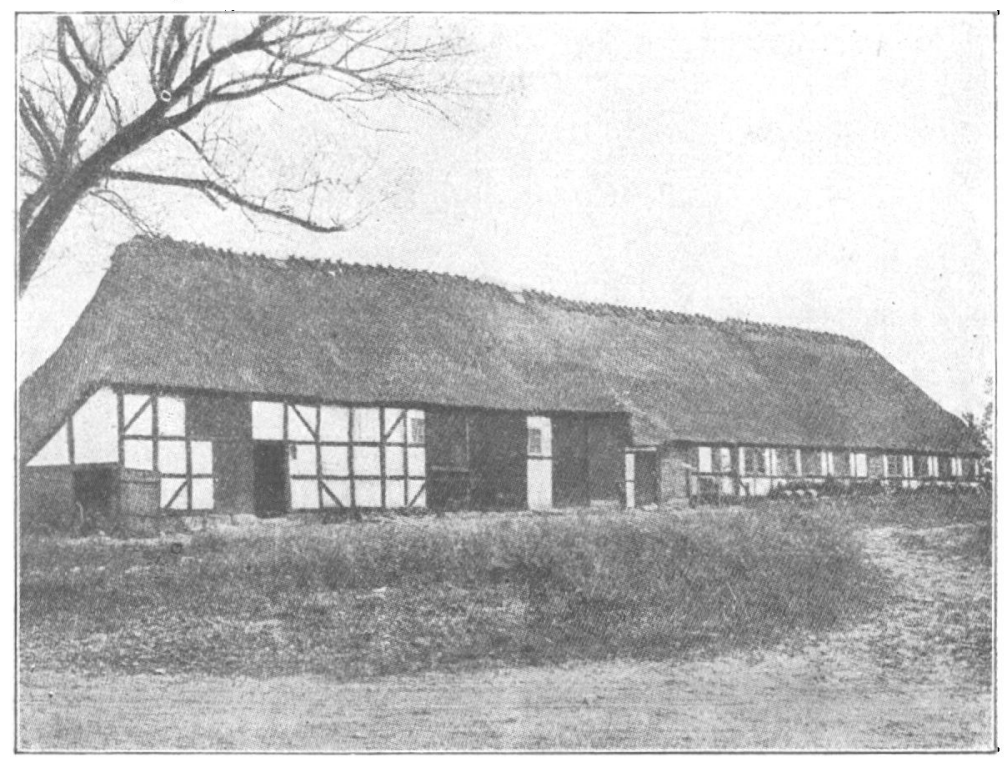

Fig. 5. Gaard i Fjelby, Lysabild Sogn.

(Forf. fot. 1922. - Efter Danmarks Folkeminder Nr. 31).

bindelse med, og endelig den vekslende Række af Loer og Lader. I Beboelsen findes 2 Skorstene, den ene med Bagerovn liggende $\mathrm{i}$ "F ra m g u l v e t" (1), og ved Siden af Ovnen er $\mathrm{P}$ i ge $\mathrm{ka} \mathrm{m}$ meret (12) indrettet. Den anden Skorsten findes $\mathrm{i} K \emptyset \mathrm{k} k \mathrm{e}$ et (2), og fra Ildstedet her kan der fyres i Bilæggeren i "Sønd e rdørnse t« (3), den egentlige Dagligstue. Bag Kiskkenet findes "æ $\mathrm{R}$ in d « (2'), som er et Rum for Opvaskning, det kaldes ogsaa "T o k a m m e r e t«, og bag Sønderdørnset findes en "B o d « (9), et Fadebur eller Spisekammer. Betegnelsen "Dørns«, 


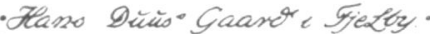

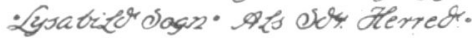

- Ofonderórg Ae.

ditciatcononotan

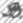
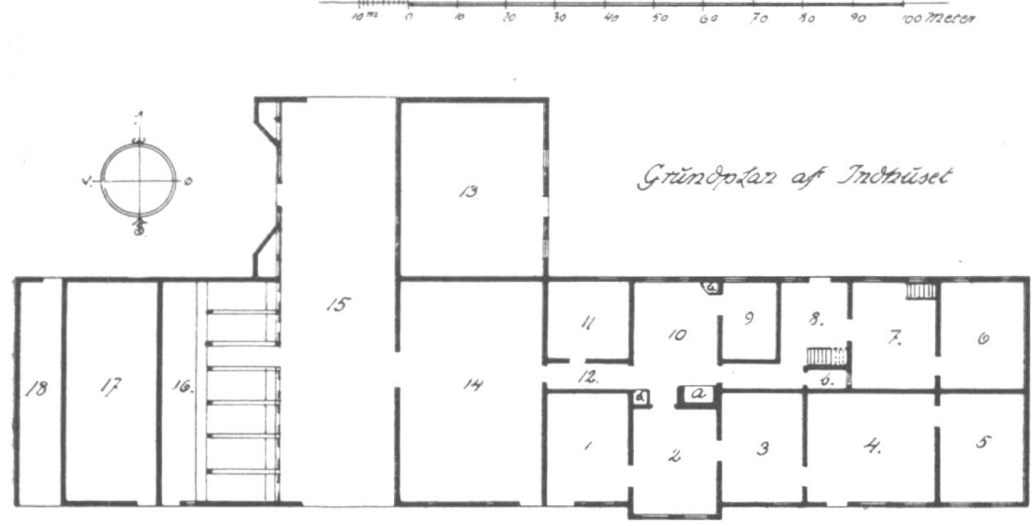

10 merom

Fig. 6. Grundplan af en Gaard i Fjelby.

(Efter Opmaaling $i 1918$ af Marinearkitekt Klix).

Situationsplan : A) Indhus. B) Aftcogtshus. C) Stalde. D) Bagehus. E) Hielm * F) Sandhuse. G) Kaalgaard.

Indhuset: 1) Framgulv. 2) Dorns. 3) Lilledorns. 4) Pisel. 5) Sonderkolle. 6) Narrekel(e. 7) Malkekammet. 8) Tokammer. 9) Pigekammer. 10) Kokken. 11) Karlekammer. 12) Gang. 13) Kalve- og Svinestald. 14) Kostald. 15) Lo. 16) Hestestald. 17) Kornkiste. 18) V'ognskjul. a) Aaben Skorsten. b) Skabe. c) Smaaskabe. 
Dørnsk eller Dønsk er af slavisk Oprindelse og betyder en Opholdsstue til at opvarme ved en Ovn. Sønderdørnset kaldes ogsaa Dagligdørns, den daglige Opholdsstue, og ofte havde man desuden et "L il l ed ø $\mathrm{n} \mathrm{s} \ll$, - her paa Planen mærket j, - en mindre Stue som ikke kunde opvarmes og som paa enkelte Steder brugtes som Sengekammer, idet den ligesom Dagligstuen kunde have fast indbyggede Alkover. Ved Siden af Lilledørnset findes $" B \mathrm{r}$ u de $\mathrm{ka} \mathrm{m} \mathrm{me-}$ ret" (7) som nærmest har været et Rum for Opbevaring af Kister til Tøj ligesom Boden eller » $\mathbf{N} ø \mathbf{r} \mathbf{r} \mathrm{e}-$ k o Il e n« (9) bag ved Lilledørnset og Brudekammeret.

Fra Framgulvet gaar man direkte ind i $\mathrm{Hes}$ estalden (I'), hvori Karlekammeret (13) er indbygget, og mellem Heste og Kostalden (I) ligger Foderloen (e Fuegol) II'. Undertiden var Staldene dog byttet om, saaledes at Kostalden laa nærmest Beboelsen. I Loerne er der anbragt Porte, saaledes at man kan køre ind med Avlen eller Kornet, og aflæsse hver Sædart i $\sin$ Lade eller $» K$ is $t$ e«, som de ogsaa kaldes.

Hvorledes et saadant enlænget Hus ser ud ude fra, ser vi af Billedet Fig. 5, der viser et Indhus til en Gaarll i Fjelby i Lysabild Sogn paa Sydals. Paa Tømmerstykket over en af Indgangsdorene fandtes Indskriptionen: JØRGEN HANSEN DUUS og ANNA MARIA JØRGENS LOD DETTE HUUS OPREJSE DEN 5. JUNI ANNO 1809, hvilket viser, hvor seigt og hvor længe den aisiske Befolkning holdt fast ved deres gamle Byggeskik. Karakteristisk ved Inskriptionen er dette, at Hustruen beholder Mandens Fornavn som Efternavn, et Træk, der genfindes overalt i alsiske 
Inskriptioner, hvor Navne nævnes. Iøvrigt lægger man paa Billedel Mærke til den Todeling, som karakteriserer Bygningen, idet Beboelsen har lavere Ydervegge, medens Udhusenes Ydervagge har tre Tavl i Højden, et Træk, der findes overalt paa Als, og llensigten dermed er sikkert den at skaffe Laderne storre Rumindhold, og skaffe Tagrum over Staldene til Opbevaring af Foderet. Billedet, Fig. 6, viser en Situationspian og Grundplanen af denne Gaard. Gaarden bestaar foruden Indhuset $\mathbf{A}$ af flere Bygninger: 2 smaa Stalde $C$, et særskilt $» B$ a g e h $u s \ll D$, et stort Aftregtshus $B$, som ogsaa kaldes »e $O p$ h o l d ", en "H j e l m « E med en Gennemkørsel, som ogsaa kaldes »e A's k a a samt et Par smaa S a n d h u s e $F$ til Gulvsand, beliggende ved Hegnet omkring »e K a lg a a«, - Kaalgaarden G, som var Nyttehaven. Selve Grundplanen har et Korshus mod Nord, men llummene er de sædvanlige, og man ser, at selv om Huset er sent bygget, er det kun faa af Beboelsens Rum, som kan opvarmes, der findes kun én Skorsten. Man kommer fra Gaarden ind i Framgulvet 1, og derfra ind i Dørnset 2, Lilledørnset 3, "P i s e l e n « eller Storstuen 4, som ikke kan opvarmes, og yderst Sønder-Køllen 5, der ligesom Nørrekøllen 6 var et Kiste- og Skabsrum ogsaa kaldet "Tøjk a m m e r«. Ved Siden af Nørrekøllen findes $M æ 1 \mathrm{kek} \mathrm{am} \mathrm{me-}$ re $t 7$ med Udgang til Tokammeret 8 , hvori er et lille mørkt Skabsrum b. Bag Dørnset ligger Køkkenet 10 , og denne Placering af de to til dagligt brugte Rum genfinder man overalt $i$ saavel æeldre som yngre alsiske Huse, som Regel saaledes, at Dørnset ligger mod Syd og Køkkenet bag dette, mod Nord. I Køkkenet findes den store aabne Skorsten a og et Par Smaaskabe c, og umiddelbart op til Køkkenet ligger Pige- 
kammeret 9. Saavel Køkkenet som Karlekammeret 11 er ved Gangen 12 forbundet med Kostalden 14,
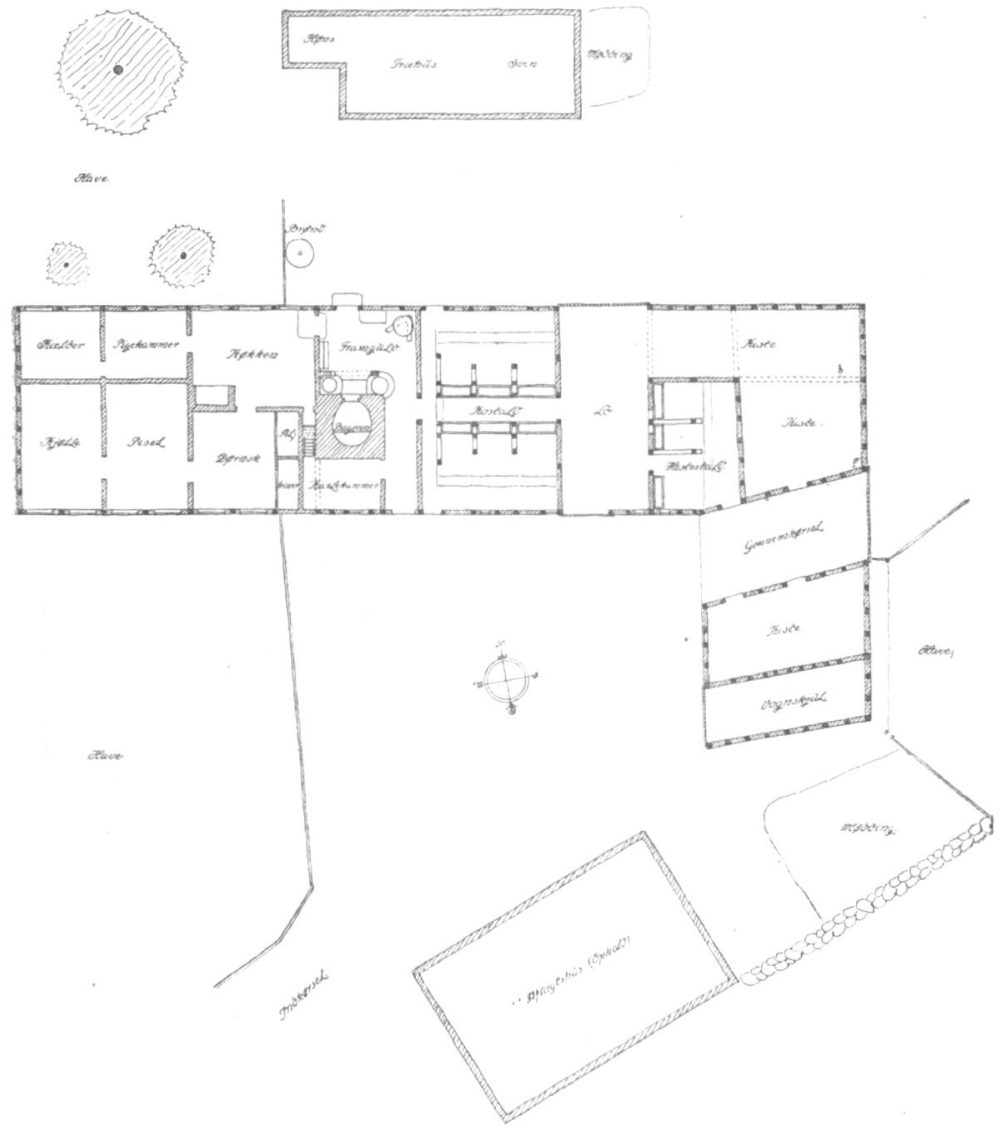

Fig 7. Grundplan af et Boelsted i Torup, Svenstrup Sogn.

(.Maalt af Forf. i 1923. - Efter Danmarks Folkeminder Nr. 31).

hvorfra man kommer ud i Loen 15. Herfra kan man fodre Hestene i Stalden 16, medens man til de øvrige Rum: Kalve- og Svinestalden 13 og Kisten 17 samt Vognskjulet 18 maa gaa ind fra Bygningens udven. dige Sider. 
Fraset det anselige Aftægtshus ved denne Gaard, er det jo egentlig kun Smaabygninger, der hører til denne flerlængede og større Gaard, og at det samme gaelder den mindre Gaard, ses af Fig. 7, der viser en Grundplan af et Vinkelhus, en Halvgaard eller Boelsted i Torup i Svenstrup Sogn, paa Nordals, hvortil

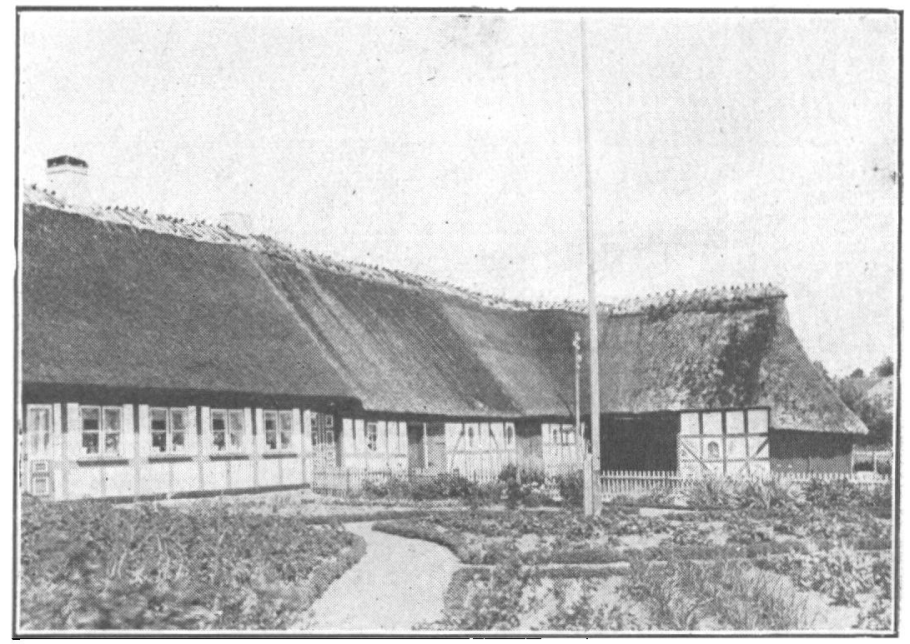

Fig. 8. Boelsted fra Torup i Svenstrup Sogn. (Forf. fot. 1923).

horer ca. 23 Tdr. Land. I Hovedtrækkene er Indretningen den samme som i de tidligere viste Grundplaner, her har vi blot en $\aleph K æ l \mathrm{~d}$ e r« eller et Forraalskammer liggende bag Sønderkøllen, og ligesom ved de øvrige Planer ligger Dørnsket med Alkoverne mod Syd og Køkkenet med den aabne Skorsten mod Nord. I én Retning adskiller dog Planen her sig fra de tidligere, idet Framgulvet sikkert oprindeligt har indtaget hele Husets Bredde, og Karlekammeret er senere indrettet. Dette Træk er utvivlsomt meget gammelt, og Mejborg synes at have fundet noget lignende i et Hus, som man har ment at skulle være fra det 
16. Aarhundrede. Huset her er dog ikke slet saa gammelt, idet en Dørhammer, nu indsat som Fyldetømmer i Vinkelfløjen, har følgende Inskription: ANNO 1714. DEN 9 IVNI CKS HAT DISEN HAVS.

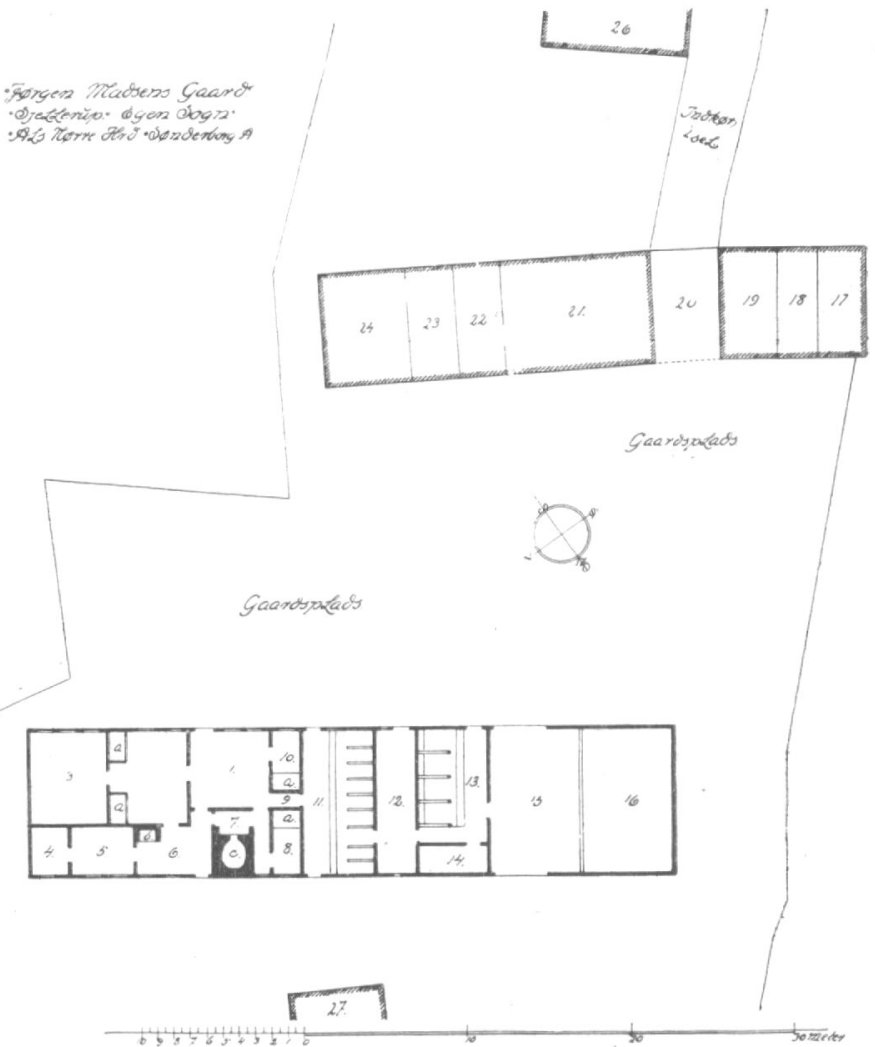

Fig. 9. Grundplan af en Gaard i Sjellerup. (Tegnet efter Matrikelkort og en Skizze, meddelt af Jorgen Nielsen $i$ Guderup).

1) Framgulv. 2) Dorns. 3) Pisel 4). Malkekammer. 5) Lilledons. 6) Kokken. 7) Bagehus. 8) Pigekammer. 9) Gang. 10) Karlekammer. (1) Kostald. 12) Lille Lo. 13) Hestestald. 14) Follade. 15) Store Lo. 16) Kornkiste. 17) Redskabsrum. 18) Huggelade. 19) Halmiade. 20) Genncmfart. 21) Kornkiste. 22) (iaasesti. 23) Faare- og Kalvesti. 24) Holade. 26) Svin og Hons. 27) Tralade (Braendsel). a) Alkover. b) Aaben Skorsten. c) Bagerovn.

D. B., men man ser altsaa, at det store Framgulv, der gik fra Væg til Væg, indrettedes i de alsiske Bønderbygninger endnu i Beg. af det 18. Aarh. Ligesom ved 
de ovrige Planer ligger Staldene, - her Kostalden, lige op til Framgulvet, som sædvanligt adskilte af en Foderlo, og Vinkelfløjen er her senere tilføjet. Som mindre Bygning findes her et "T $r æ h \mathrm{u} s$ eller en Trælade, et Brændselshus, der her ogsaa indeholder Svinesti og Hønsehus. Selve Huset, som gennem Tiderne er blevet ombygget hist og her, ses paa Billedet, Fig. 8, der viser Bygningens Sydside ud mod Vejen med en yngre, men pyntelig Prydhave foran. Laderne har de for omtalte tre Tavl i Højden, og til Vinkelfløjen er her bygget et Vognskjul. Den Art Tilbygninger kaldes i Folkemaal paa Als et $" \mathrm{~K} \mathrm{a-}$ vajs la g«, muligvis fordi de har en vis Lighed med et saadant, hvad Formen angaar.

Den tolæengede Parallelgaard, som tidligere har været en meget kendt og udbredt Type i vort Land, og som før nævnt ogsaa kendes paa Als, ses paa Billedet, Fig. 9, der viser en Grundplan af en nu nedrevet Gaard i Sjellerup i Egen Sogn. Vi finder her de sxdvanlige kendte Boligtræk, dog med den Andring, at man fra det store Framgulv (1) kommer ind i Dørnset (2), som her vender mod Nord, medens Køkkenet (6) vender mod Syd. Den store Stue, Piselen (3), er ligeledes her en Stue, der ikke kan opvarmes. Piselen har i de sønderjydske Huse altid været et rigere udstyret Kiste- og Klædekammer, kun brugt som Opholdsstue ved festlige Lejligheder, ved hvilke man undertiden ryddede den for Møbler. Bag Piselen ligger her et Mælkekammer (4) og et Lilledørns (5). Ved Siden af Køkkenet ligger en Bagestue (7) med Bagerovn (c), og Beboelsen afsluttes mod bist med et Pige- og et Karlekammer (8 og 10) adskilt af en Gang (9), ad hvilken man kommer ind i Kostalden (11). Dernæst følger Foderloen, her kaldet 
Alsiske Bandergaard ${ }^{\circ}$.

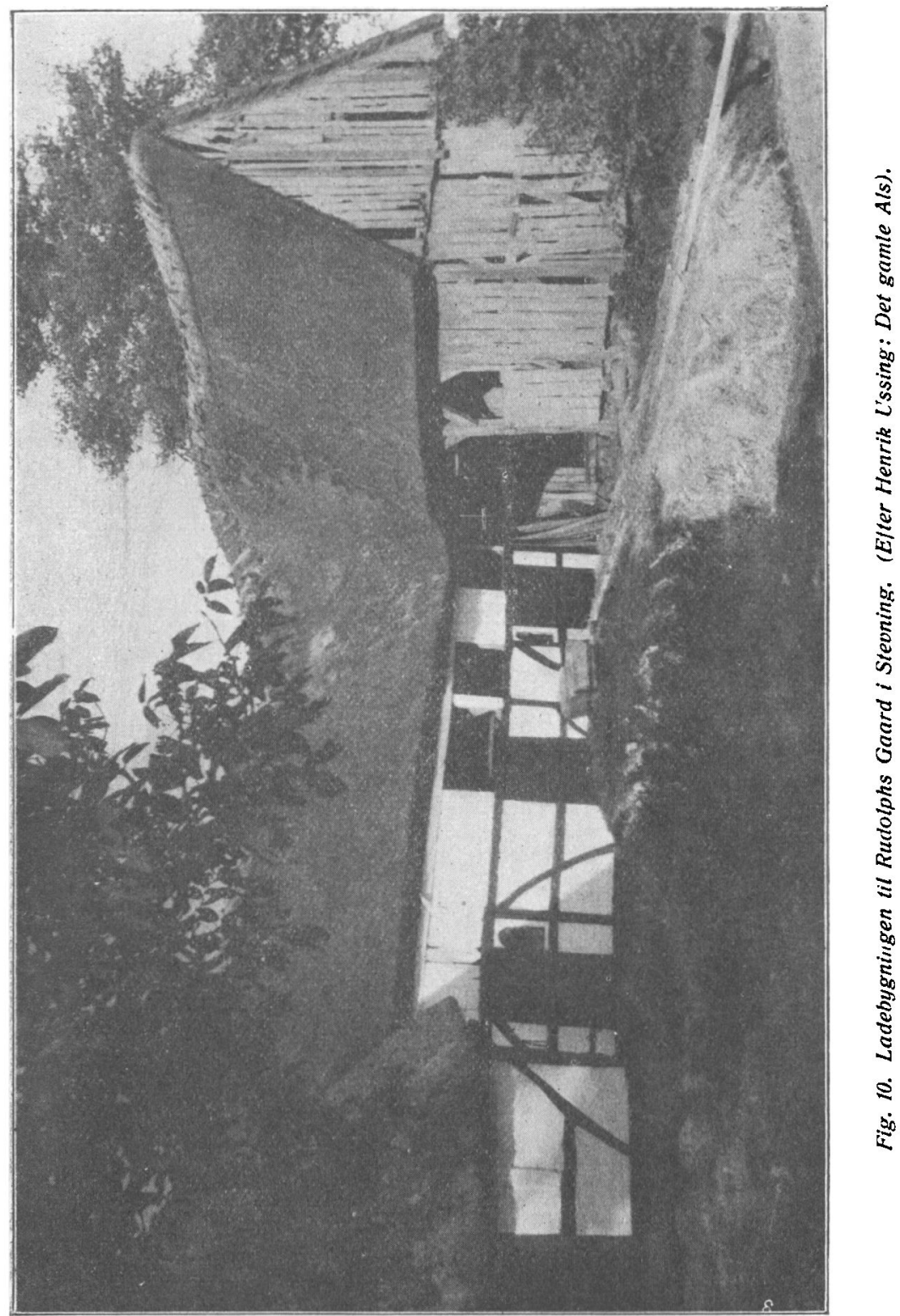


den lille Lo (12), og Hestestalden (13) med et Følrum, samt den store Lo (15) og en Kornkiste (16). Ladebygningen indeholder Redskabsrum (17), Huggelade (18), Halmlade (19), Porten eller "Ge n n e m f a rt e n« (20) ogsaa brugt til Vognskur, den store Kornkiste (21), Gaasesti (22), Faare- og Kalvesti (23) og Hølade (24). Endelig findes et Par mindre Smaalader til Svin og Hons (26) og formentlig en Trælade (27) til Brændsel. Paa Grund af at Indhuset er indrettet paa alınindelig alsisk Maade, adskiller den alsiske Parallelgaard sig fra Landets øvrige, idet man ved de nordjydske Gaarde har henlagt baade Stalde, Lo og Lader til Udhusbygningen og samlet alt i denne ene Bygning, medens Stuehuset kun indeholdt Beboelsen.

En noget lignende Gaard ses af Billederne, Fig. 10,11 og 12, hvoraf det første viser Ladebygningen til Rudolphs Gaard i Stevning i Svenstrup Sogn, en af Als's mest bekendte Gaarde, og som vel ingen, der har gæstet Als, for at gøre sig bekendt med Almuekultur, har undladt at besøge. Det er dog snarere det maleriske ved Gaarden, og Bygningernes smukke Ydre, der har gjort den særligt bekendt fremfor andre-Gaarde paa Als, men især den gamle Hjelm, der sikkert stammer fra den første Halvdel af det 17. Aarhundrede, og som er en af de ærværdigste Bønderbygninger paa Als, maaske den allerældste. Ladebygningen, Fig. 10, der er sammenbygget med Hjelmen, er formentlig opført $i$ den sidste Halvdel af det 18. Aarhundrede, men forinden har Hjelmen dog været fritstaaende, og Landevejen har før gaaet igennem den. At dette maaske har været Tilfældet ogsaa andre Steder, synes næsten det gamle nørrealsiske Mundheld: "Han sta'e i e Vej, lisom Pæ Lindgaas 
Hjelm« at vidne om. Paa Billedet, Fig. 11, ser vi Indhuset, hvor der paa et Brædt over Indgangsdøren til Beboelsen staar: "C. C. R. Soli Deo Gloria. A. S. C. D. 6. April $A^{*} 1791$ «, - og over Døren til Foderloen er der i Tømmeret indhugget følgende Indskrift: "Christien Rudolf. 1798. D. 12. Jun. Aanhofe RC«. Indhuset

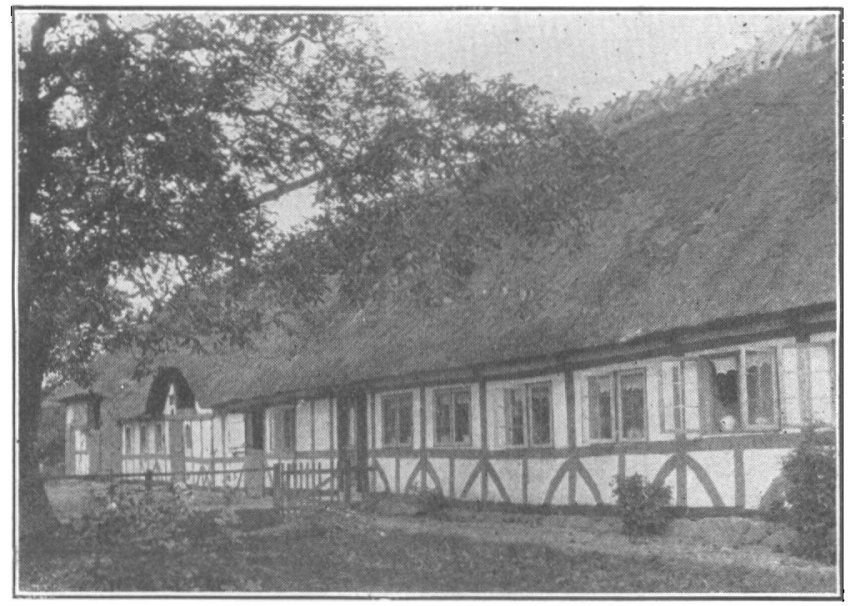

Fig. 11. Indhuset til Rudolphs Gaard i Steoning. (Efter "Dansk Udsyn". 5. Aarg. 3. H.)

bestaar altsaa af 2 Bygninger, opførte hver for sig med 7 Aars Mellemrum af Christian Christensen Rudolph, hvilket Slægtsnavn allerede knyttedes til Gaarden i 1698. Paa Billedet lægger man især Mærke til de mange Skraabaand i de underste Tavl, der for starste Parten er krumme. Dette Træk har været meget yndet $\mathrm{i}$ det alsiske Bindingsværk.

Grundplanen af Gaarden ses paa Billedet, Fig. 12, og den er ikke synderligt anderledes end ved de andre Gaarde, som her er blevet omtalt, dog maa man lægge Mærke til at Bagerovnen her er flyttet ud af Indhuset, og henlagt til et særskilt Bagehus (21), der 


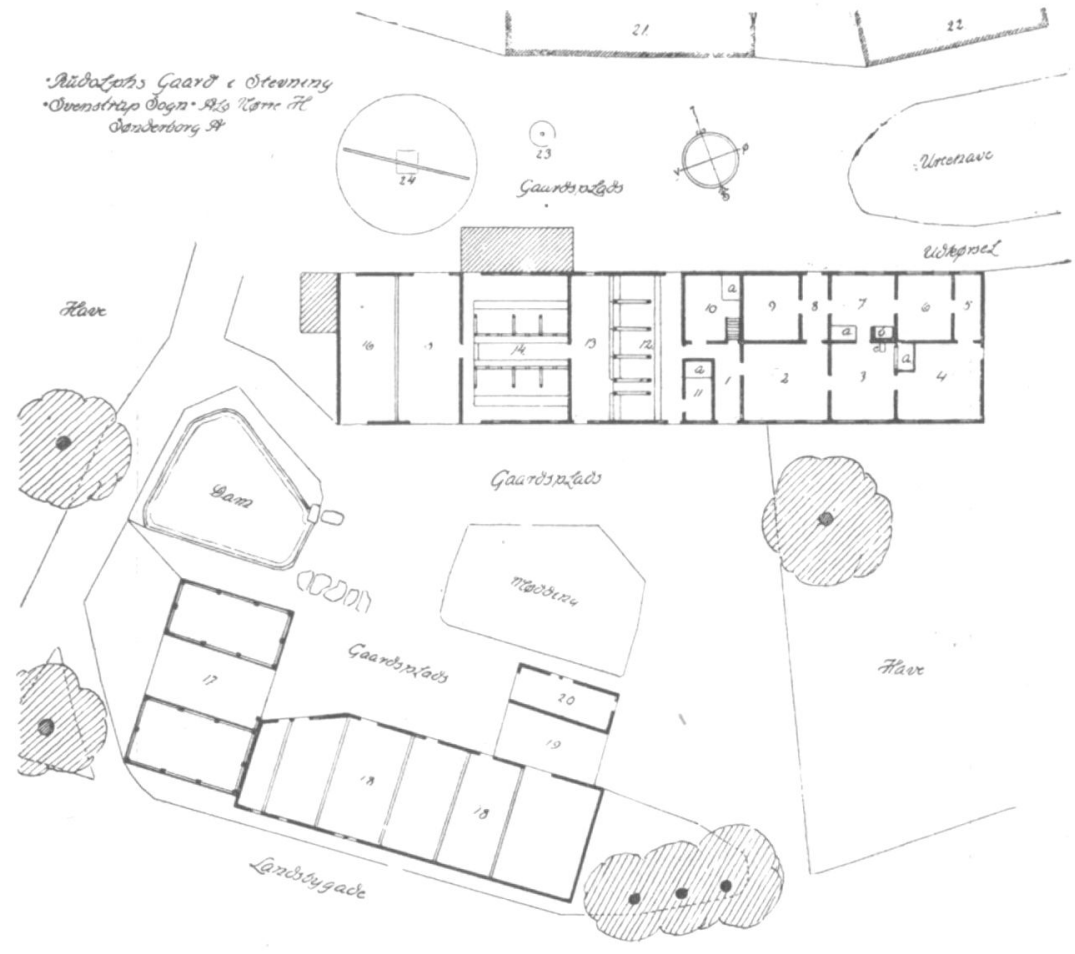

Fig. 12. Grundplan af Rudolphs Gaard i Stevning. (Opmaalt 1923 at Forf.).

1) Framguto. 2) Pisel. 3) Derns. 4) Sonderkollt: 5) Brudekammer. 6) Lilledorns. 7) Kokken. 8) Rind. 9) Koolder. 10) Pigekammer. 11) Karlekammer. 12) Hestestald. 13) Foderlo. (4) Kostald. 15) Lo. 16) Kornkiste. 17) Hielm. 18) Loer. 19) Port. 20) Vognskjul. 21) Bagehus. 22) Aftoggtshus. 23) Kaeld (Brond). 24) Hestegang. d) Alkover. b) Aaben Skorsten. c) Biloggerovn.

sammen med et Aftægtshus (22) afgrænser en Gaardsplads nordfor Indhuset, hvori der findes en Brønd, "en Kæld" (23) og en Hestegang (24). I selve Indhuset genfinder man det sædvanlige Træk med Køkkenet (7), der er anbragt Nord for Dornset (3), og det ses, at der i Kokkenet findes en Alkove (a). Mellem Framgulvet (1) og Dørnset er Piselen (2) indskudt, og yderst ved Østgavlen findes Sønderkøllen (4) og Brudekammeret 
(5), og mellem dette og Køkkenet findes Lilledørnset (i). Ved Siden af Køkkenet ligger "e Rind" (8) og en Kælder (9), og derefter følger Pigekammeret (10) og Karlekammeret (11), hvorfra er direkte Adgang til Hestestalden (12). Derefter følger Foderlo (13), Kostald (14), Loen (15) og Kornkisten (16). I Ladebygningen findes den omtalte gamle Hjelm (17) og et Par Loer (18), en Port (19) og et Vognskjul (20). Paa den egentlige Gaardsplads findes Møddingen og en lille Park til Vanding af Kreaturerne.

Som for omtalt var den trelængede Gaard især yndet paa Als i Slutningen af det 18. Aarh., og paa Billedet, Fig. 13, ses Grundplanen af en saadan typisk Gaard fra Holm i Nordborg Sogn. Indhuset har den sædvanlige Rumfordeling med Hovedrummene Køkken (2) og Sønderdørnset (3) bag hinanden samt Pisel (4) med bagved liggende Kølle eller Kløve (5), Tokammer (6) og Kælder (7). I Indhuset findes kun én Skorsten, idet Bagerset er henlagt til et særskilt Bagehus (21), bag hvilket findes Svinesti, samt Vedskjul pller Træhus og Huggehus.

Saadanne Bagehuse har visse Forfattere ikke tidligere tiltroet nogen særlig høj Alder, og det har da dette Hus ikke heller, idet Gaarden formentlig er opfort omkring Aar 1800, men Bagehusene synes dog at have været opførte som særlige Bygninger paa Als allererde for Midten af det 18. Aarh.

I Indhuset $\mathrm{i}$ Gaarden her gaar man fra Framgulvet (1) direkte ud i Kostalden (10), og derefter kommer (len sædvanlige Foderlo (11) og Hestestald (12) samt Karlekammer (13). Adskilte af et Vognskjul (14), kommer endelig i Vinkellængerne mod Vest og Nord et Par Follader (15), samt Kisterne til Rug, Byg og 


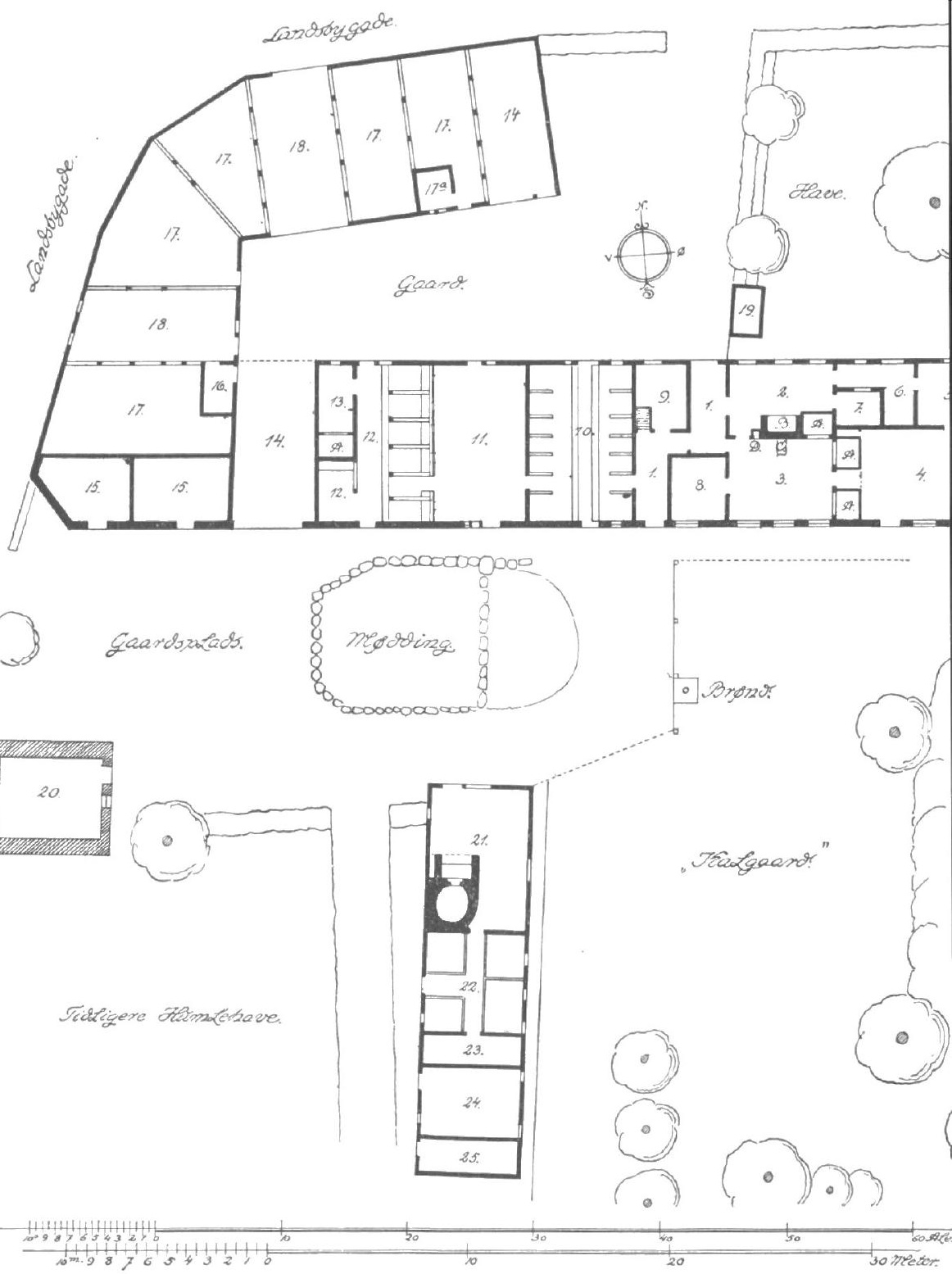

Fig. 13. Grundplan af en Gaard fra Holm. (Maalt af Fort. $i$ 1923).

1) Framgulv. 2) Kokken. 3) Dorns. 4) Pisel. 5) Klove. 6) Rind. (Opvaskerum). 7) Koelder. 8) Brudekamme1. 9) Bod (Spisekammer). 10) Kostald. 11) Foderlo. 19. Hestestald. 13) Karlekammer. 14) Vognskiul. 15) Follade. 16) Aunelade. 17) Byg-, Rug-og Hoedekister (Lader). 17a) Hons. 18) Tarskeloer. 19) Sandhus. E0) Karunkel (Kartoffelkaelder). 21) Bagehus. 22) Soinesti. 23) Vedskjul. 24) Huggehus. 25) Vedskinl. A) Alkover. B) Ildsted. C) Bilaggeroun. D) Skab. 
Hvede (17) adskilte af Tærskeloerne (18). Endvidere findes foran Indhuset det sædvanlige alsiske Sandhus til Gulvsand (19) og ved Gaardspladsen en fritliggende Kartoffelkælder (20), den saakaldte $» \mathbf{K}$ ar u n k e l«, som tidligere har været en af de sædvanligste mindre alsiske Bygninger, der sjældent manglede ved en Gaard, og en saadan ses paa Billedet,

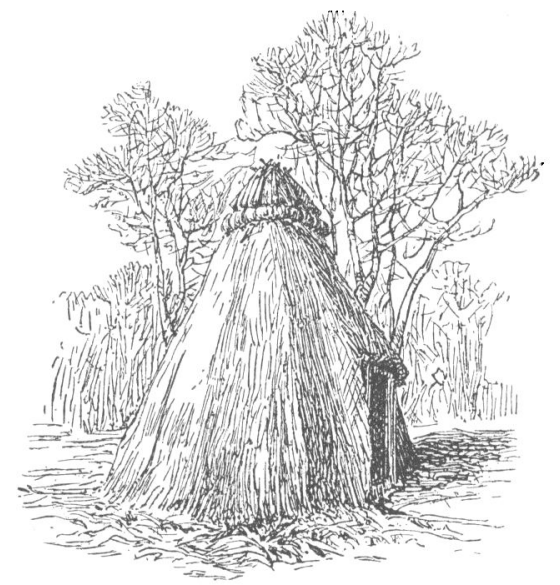

Fig. 14. Karunkel fra Nordals.

(Efter R. Mejborg: Slesvigske Bondergaarde).

Fig. 14. Nogle Steder kunde Karunklen dog ogsaa have Form som det almindeligt kendte jydske Spændhus, som egentlig blot er et Tag henstillet paa Jorden. Paa Billedet, Fig. 14, lægger man især Mærke til den ejendommelige runde Krans foroven, som har været meget anvendt, og som i hvert Fald tidligere sjældent savnedes paa Øens Straatage.

Sandhuset, som ligeledes er en almindelig alsisk Bygning, ses paa Billedet Fig. 15, som tillige viser Indhuset af den trelængede Gaard fra Holm, hvis Grundplan findes paa Fig 13. Da Sandet indeholdt 
H. Zangenberg.

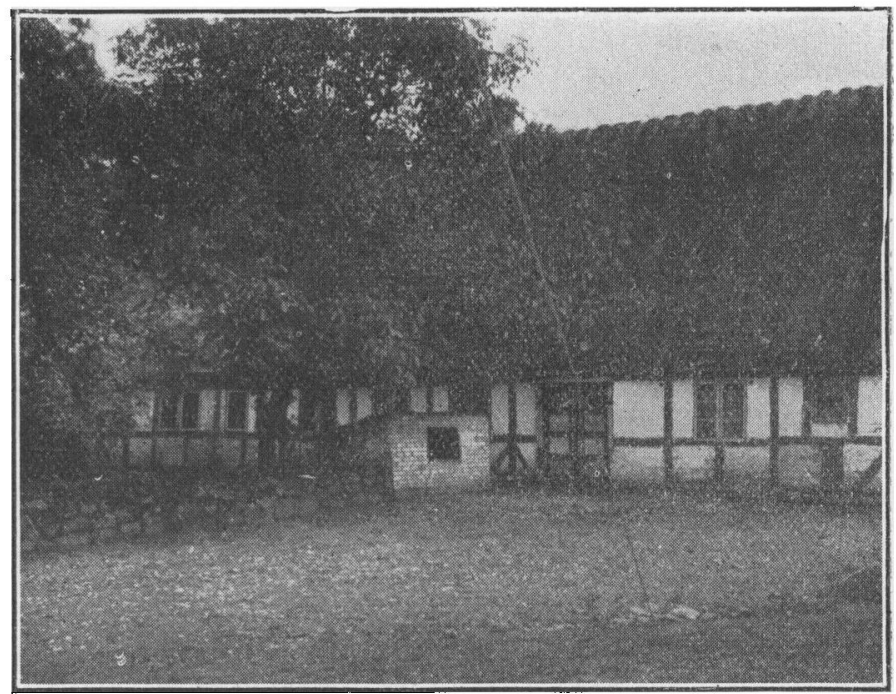

Fig. 15. Gaard fra Holm i Nordborg Sogn. (Forf. fot. 1922).

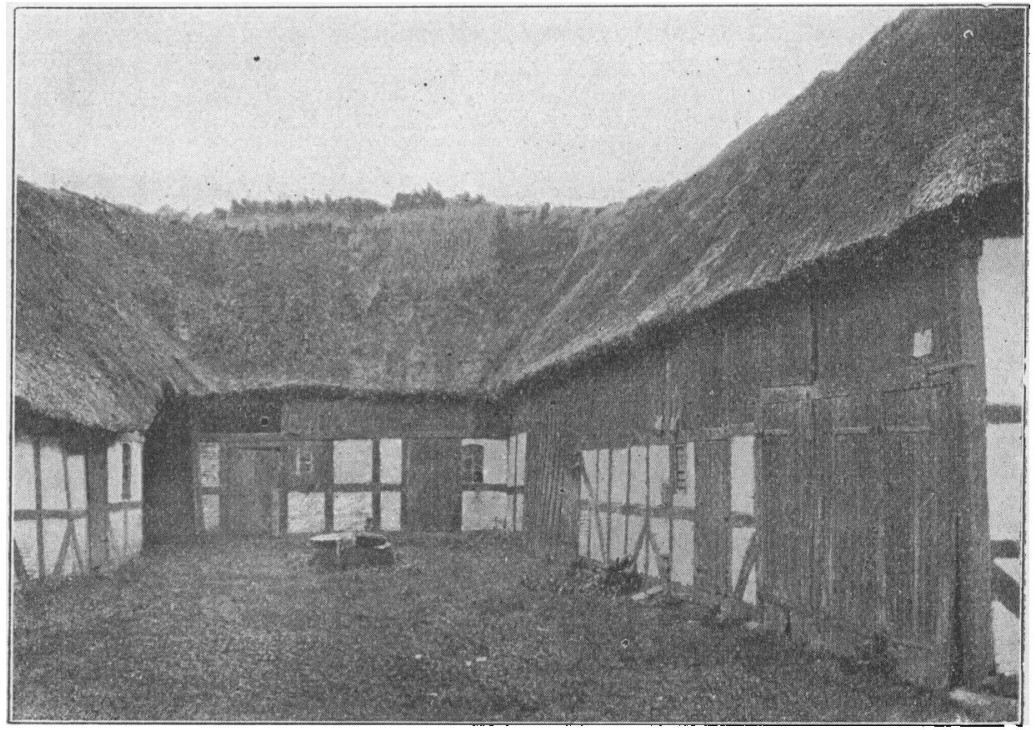

Fig. 16. Gaard tra Holm i Nordborg Sogn. (Forf. fot. 1922). 
Syre, som vilde angribe Træværket, murede man disse Huse og dækkede Taget med Tegl. Paa Billedet ses Indhusets pyntelige men ikke særligt gamle Indgangsdør, og det blyindfattede Vindue giver en Forestilling om Husets tidligere Vinduer, som der ses et Glint af yderst til venstre. Billedet Fig. 16 viser Gaardspladsen i samme Gaard, omsluttet af de tre Floje, hvoraf Ladelængerne, som almindelig Skik er paa Als, har 3 Tavl i Højden, og det øverste er lukket med Brædder eller Trælenme. Tavlene er de fleste Steder udmurede med brandte Sten, og det synes som om man tidligt har begyndt at indføre dette i alsiske Bygninger, da man ofte ser Monstermurverk i Tavlene, som stammer fra den sidste Halvllel af 18. Aarh. Man har ogsaa mange Steder gaaet endnu videre, idet man har grundmuret Sydsiderne i Bindingsværksgaardene, som er den Side, der er mest udsat for Vind og Vejr, og man kan derfor finde Gaarde, hvor Nordsiden er af Bindingsværk og Sydsiden af Grundmur, hvad der netop var Tilfældet ved den her omtalte trelængede Gaard i Holm.

Man har dog ogsaa helt grundmurede ældre Gaarde paa Als, og grundmurede Længer er blevet indfort $i$ Begynde]sen af 1770erne, idet man $i$ hvert Fald i Ketting finder et grundmuret Indhus med Aarstallet 17\%3. Ved Indførelsen af de grundmurede Landbygninger paa Øen er det vistnok sandsynligt, at det især er Præstegaardene der har vist Vejen, idet der findes flere, ældre og grundmurede Bygninger, som hører til Præsteembederne. En af de anseligste grundmurede Bondergaarde paa Øen findes i Hagenbjerg, og denne ses paa Billedet, Fig. 17, som viser Siden ud mod Landshygaden. I Frontspidsen, 
der paa Als kaldes en "K vis t", viser de indmurede Ankere, at Gaarden er opført 1791. De buede Vinduer, som er indsat i 1871, har sikkert ændret Fasadens Karakter ret stærkt, og navnlig virker de jo helt ødelæggende i Kvisten, da de her er meget for store. Husets Gaardside har en Bindingsværkskvist med et ejendommeligt fremskudt Tag foroven. Det

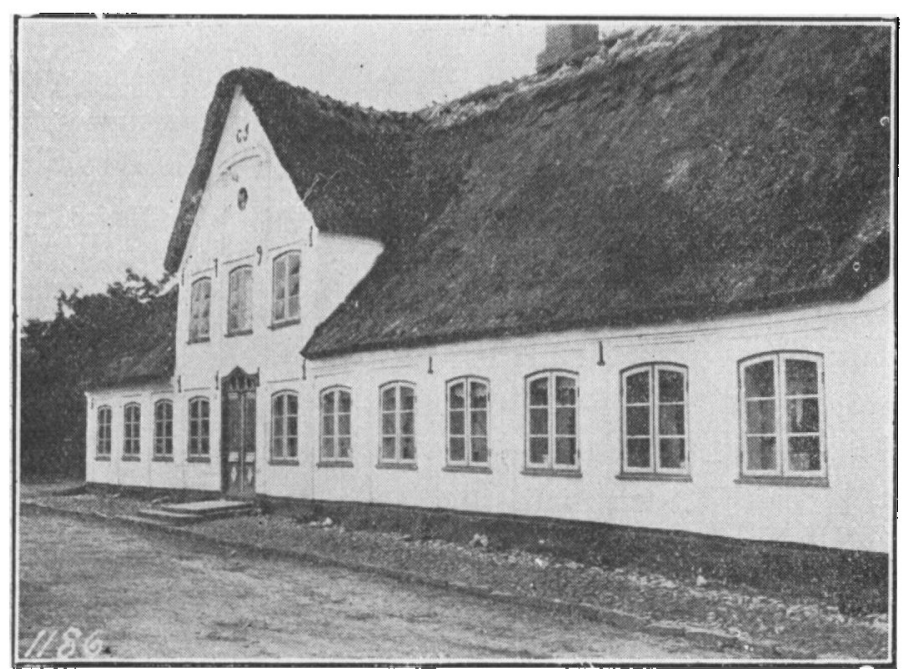

Fig. 17. Grundmuret Gaard i Hagenbjerg. (Forf. tot. 1922).

er en Kvistart, som man ikke træffer saa sjældent paa Als, især paa Bygninger, bestemt til at modtage og opbevare Korn, idet der bag det fremskudte Parti iindes et Hejseværk. I Hagenbjerg-Gaarden har der været Brændevinsbrænderi, og dette forklarer Kvistens Tilstedeværelse her. Lignende Hejseværker kunde man ogsaa se paa de alsiske Kroer, som sikkert ved Kroprivilegiet har haft Ret til at brænde Brændevin, men her fandt man ofte Hejseværket an- 
bragt udvendigt paa den knægtbyggede Gavl, der i Almindelighed karakteriserede de gamle alsiske Kroer. Hejsekvistene fandtes dog ikke alene ved Brændevinsbrænderierne, men ogsaa ved Vandmøllerne, se Fig. 18, der viser et Billede af Svensmølle i Tandslet Sogn.

Som tidligere omtalt var de vigtigste Beboelsesrum i den gamle alsiske Gaard: Køkkenet, Dørnset og Piselen, og af disse har naturligvis Piselen værei et Rum, udstyret efter Raad og Evne, eftersom man var i Besiddelse af mere eller mindre værdifulde Skabe og Kister, og der har derfor næppe været nogen anden og fastere Regel paa Als for den, end hvad der gælder for enhver Storstue i vort Lands Bøndergaarde, nemlig at Bohavet var stillet langs Væggene og saaledes understregede denne Stues Karakter af at være et pænere udstyret Klæde- og Kistekammer. Eldre Bohave findes kun sjældent i Nutiden paa alsiske Gaarde, et enkelt Sted kan der dog findes en Alkove eller et Skab fra Slutningen af det 18. Aarhundrede, der som Regel er meget smukt Snedkerarbejde. For Alkoverne findes altid to Døre, som naar helt ned til Gulvet, baade i ældre og $\mathrm{i}$ de senere indbyggede Interiører fra Empiretiden, af hvilke der findes enkelte hist og her endnu. Det var særlig i Dornset, at Alkovevæggene fandtes, og for at se, hvorledes man har indrettet Dørnset og Køkkenet i de alsiske Gaarde, vises paa Fig. 19 en Grundplan af en Gaard fra Hagelbjergmose, udflyttet fra Almsted.

Man havde her sammenbygget Hjelmen, - der bestod af Kornlader (19) og Vognskjul (20), - med Indhuset. Fra Framgulvet (8) kom man ind i Dornset 


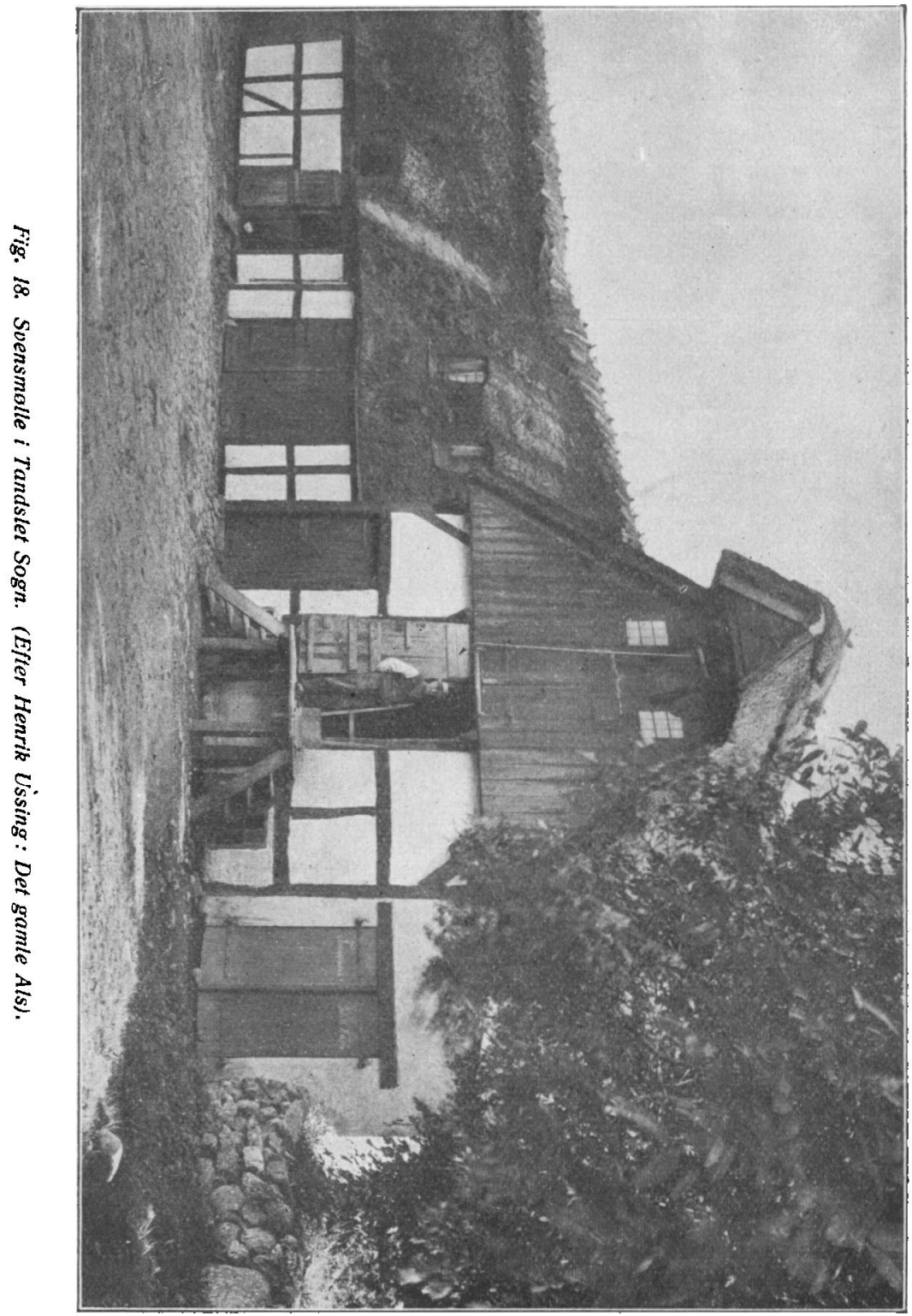




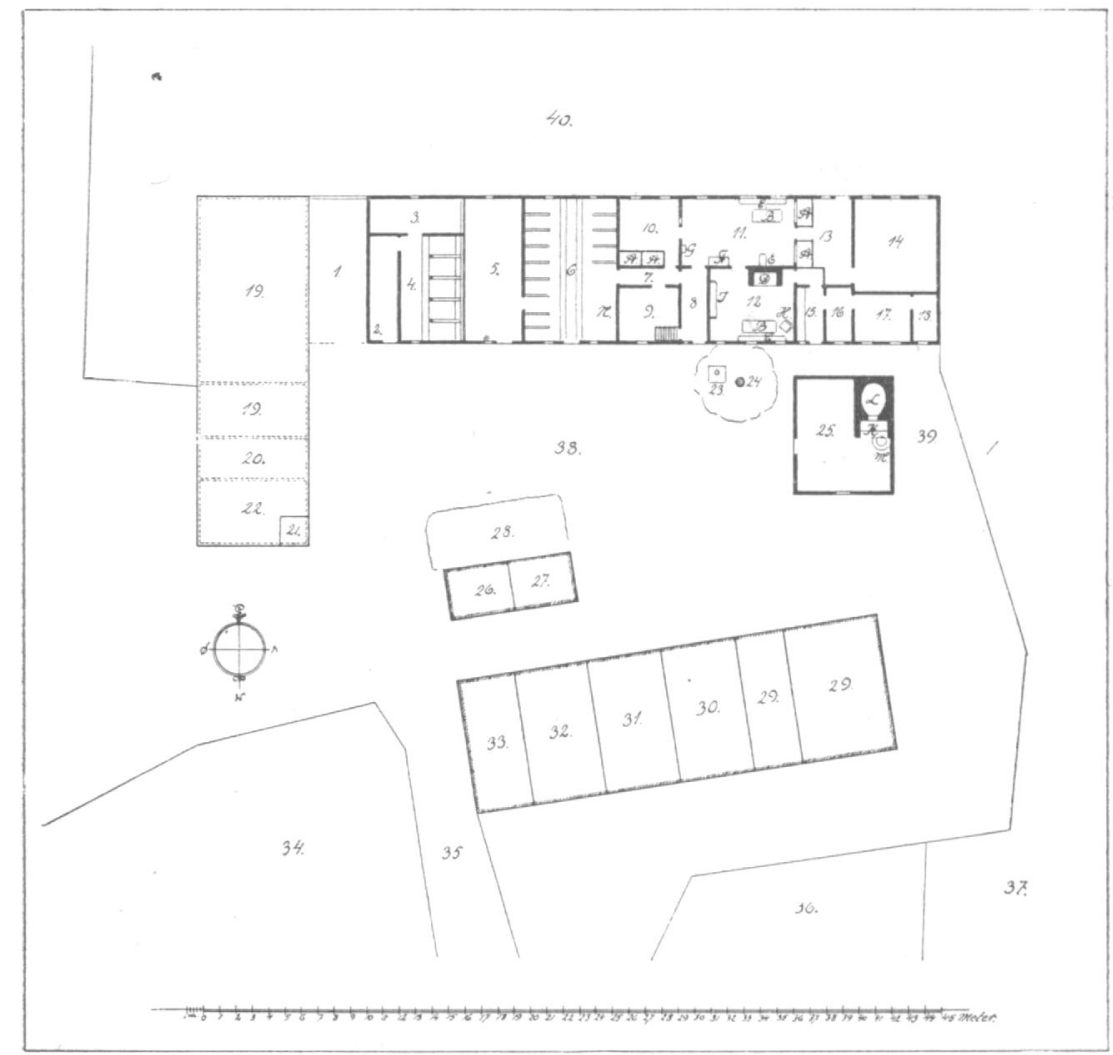

Fig. 19. Grundplan af Hagelbjergmosegaard. - Udflyttet fra Almsted.

1) Lo. 2) Seletoj. 3) Follade. 4) Hestestald. 5) Fodergulv. 6) Kostald. 7) Gang. 8) Framgulo. 9) Karlekammer. 10) Lilledorns. 11) Dagligdorns. 12) Kakken. 13) Tojkammer. 14) Kolle. (5) Tokammer. 16) Spisekammer. (7) Malkekammer. 18) Saltkammer. 19) Kornlader. 20) Vognskjul. 21) Hons. 22) Hielm. 23) Kald (Brond). 24) Lindetra. 25) Bagehus. 26) Svinelade. 27) Faarelade. 28) Modding. 29j Ophold (Aftcegtsbeboelse). 30) Vognskinl. 3I) Trcelade. 32) Hons. 33) Huggelade. 34) AEblegaard og Skov. 35) Giyw (Indkorsel). 36) Frugttroer. 37) Humlehave. 38) Gaardsplads. 39) Braendehave. 40) Kaalgaard.

A) Alkovesenge. B) Borde. C) Baenke. D) Ildsted (Skorsten). E) Biloggerovn. F) Skab. G) Uhr. H) Husbondens Sade. I) Fadrakke. K) (ldsted. L) Bageroun. M) Bryggerkedel. N) Spoltonde.

(Efter Henrik Ussing: Det gamle Als). 
(11), og her havde man straks for sig Vinduesvæggen, hvorved var anbragt en Bænk under Vinduerne (C) og et Bord, "e Dis k", foran Vinduet. Stuens vestre Væg var Alkovevæggen med Alkoverne A, hvorimellem var en Dør til det tilstødende Tøjkammer (13). Ved Skillevæggen mod Køkkenet var Jærnbilæggerovnen anbragt, og mellem Dørene til Køkkenet og Framgulvet stod et Skab til de Kopper og Kummer, som brugtes til daglig. - Paa Siden af Ovnen var der ofte anbragt en Jernplade i Væggen, som blev opvarmat af Ilden paa det aabne Ildsted i Kokkonet, og til denne var der gerne fæstet en Jærnstang, hvorpaa man hængte Strømper til Tørring. Paa Gulvet foran Jærnpladen var anbragt en Skuffe "Sk of - laat", eller "Pladeskrin«, hvori man opbevarede saadant Tøj, som stedse skulde holdes varmt, navnlig Smaabørnenes Tøj. Ved den fjerde Væg ind til Lilledørnset (10) stod stueuret (G), og ved Siden af Døren $i$ denne Væg var anbragt en Kigrude. I Kokkenet havde man en lignende Bordopstilling med en Stol (H) for Bordenden, der var Husbondens Sæde, og her spiste man for det meste; kun naar det. blev for koldt, spistes Middagsmaden i det opvarmede Dørns. Langs Væggen mod Frammerset var Fadrækken (I) anbragt, og i denne var der stillet Tallerkener og Fade, som for det meste ikke blev brugt, men kun var udstillet til Stads. Ved Døren til Dagligstuen fandtes det aabne Ildsted (D), og Skorstensvangerne bar som of test en "S k or stenshammer«, et Træstykke der bar Skorstenens fjerde Side, og heri kunde undertiden Gaardbesidderens Navn være indskaaret. I Skorstenen var anbragt en »S ods t a n g“, hvorpaa man $i$ "K e d- 
delhager", indrettede til at hæve og sænke Gryderne, kunde hænge disse over Ilden. Over Sodstangen kunde undertiden være indrettet et Røgekammer i Skorstenen, og over dette Røgekammer tørrede man Grønmalten som skulde bruges til Ølbrygning. I Tiden før 1741, - paa hvilket Tiaspunkt en Brandforordning for Als paabød, at Skorstenene $\mathrm{i}$ det mindste skulde fores en Alen over Taget - var det almindeligt, at Skorstenene udmundede $\mathrm{i}$ Tagrummet, og Røgen har da formentlig fundet Vej ud gennem et Hul i Taget, den saakaldte Lyre, som var almindelig i Landets ovrige Bøndergaarde i det 18. Aarh., eller ogsaa forsvandt Røgen gennem en aabentstaaende Lem i Gavlen. Røgsvartet Tagværk findes endnu undertiden i alsiske Gaarde, ja det underste Lag af Halm, som lagdes direkte oven paa Lægterne, kan endog være fuldstændig sortsværtet af et Sodlag, hvilket turde være tydelige Beviser for, at den alsiske Skorsten har manglet Pibe $\mathrm{i}$ ældre Tider.

Vi vil nu se noget nærmere paa den alsisk̀e Dagligstue: Dørnset. I de fleste af Landets Bøndergaarde har Husbondens Sæde altid været for Bordenden, og dette Sade var gerne ved den saakaldte Bordendebænk markeret saaledes, at det skilte sig fra de øvrige Pladser ved Bordet. Dette synes ikko at have været Tilfældet paa Als i ældre Tider, og fra enkelte Steder foreligger der Optegnelser om, at Bordet ofte stod langs Skillerumsvæggen og ikke langs Vinduesvæggen. Husbonden sad da paa en Stol for Bordenden foran Vinduerne.

At Bordet var stillet langs Skillerummet, altsaa paa tværs af Huset, er et Træk, som er et Levn aí 


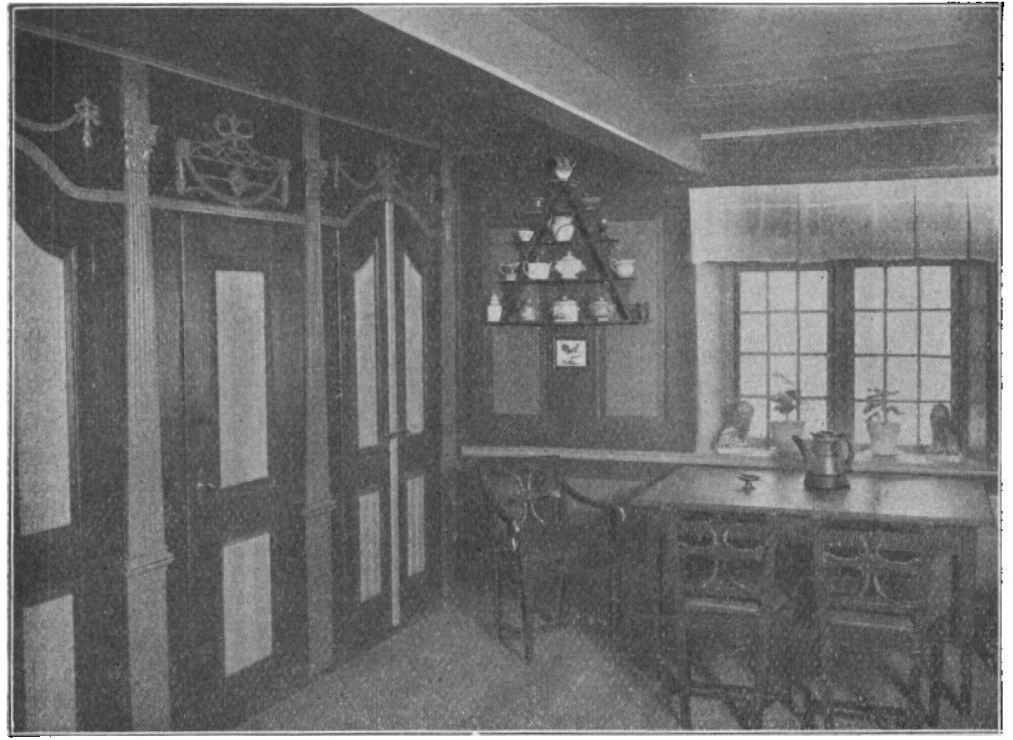

rig. 20. Dorns fra Skovby, nu i Sanderborg Museum. (Efter Henrik Ussing: Det gamle Als).

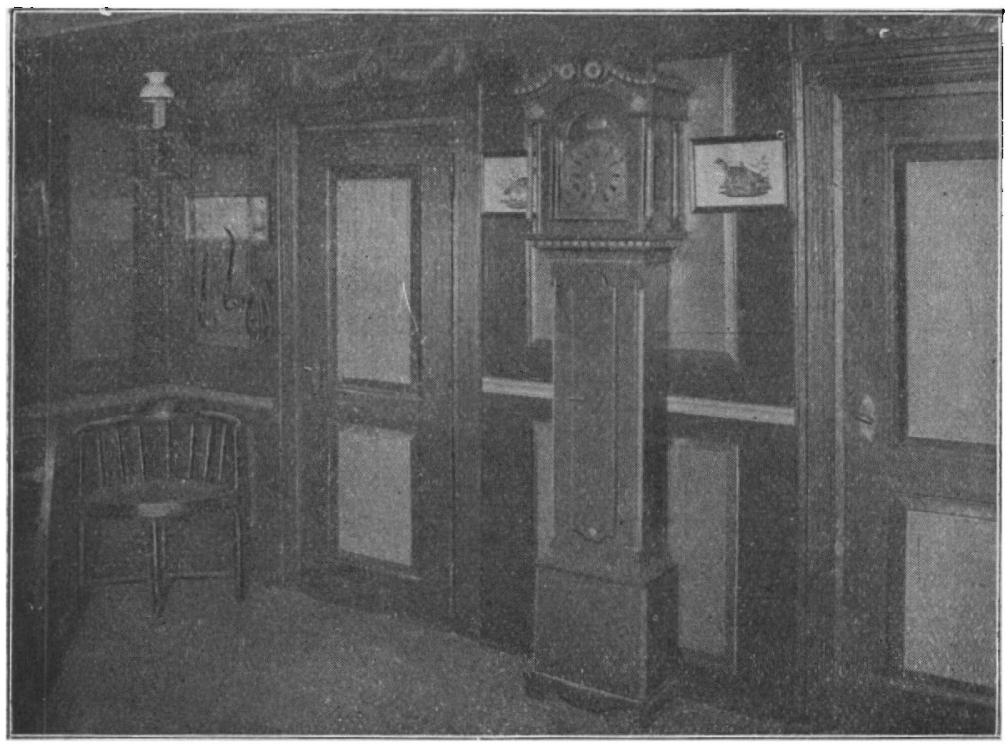

Fig. 21. Durns fra Skovby. (Se rig. zu). 


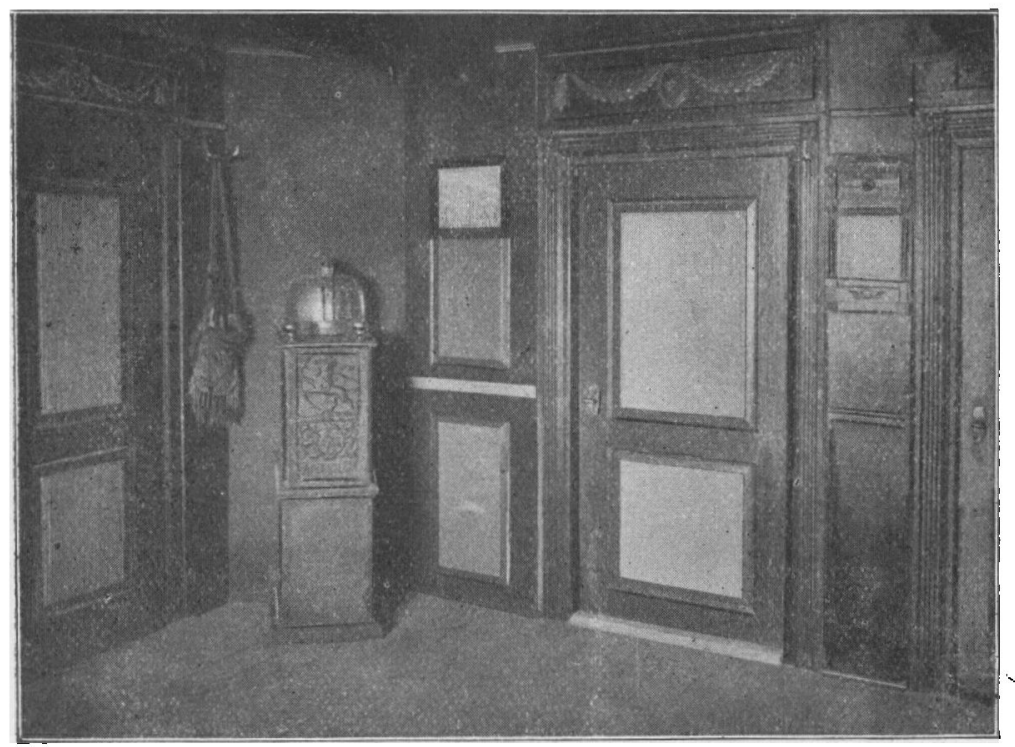

Fig. 22. Dorns fra Skovby. (Se Fig. 20 og 21).

middelalderlig Boligskik, og det har nogle Steder været bevaret paa Als helt ned mod vor Tid.

Da man indførte Renæssanceskikke, og drejede Bordet saaledes, at dette blev stillet langs med Vinduerne, bibeholdtes Husbondssædet stadig for Bordenden, og Husbonden kom altsaa derved til at sidde ved Skillerummet. Billederne, Fig. 20, 21 og 22 viser et Dørns fra Skovby paa Sydals, som nu findes paa Sønderborg Museum, og som giver et godt Billede af en saadan Stue, indrettet $i$ Begyndelsen af det 19. Aarhundrede, og som er et overordentligt nydeligt og tiltalende Stueinterior.

Paa Billedet, Fig. 20, ses Alkovevæggen og Vinduesvæggen med Disken foran. Husbondssædet er dog ikke særligt markeret her, men mange Steder var 
Husbondssædet en Stol af noget anden Form, og en saadan Stol staar $\mathbf{i}$ dette Dørns andet Hjørne; som ses paa Billedet, Fig. 21.

Denne Stoleform synes aabenbart at være gammel paa Als, og her skal blot henledes Opmærksomheden paa, hvor paafaldende disse Stole ligner vore

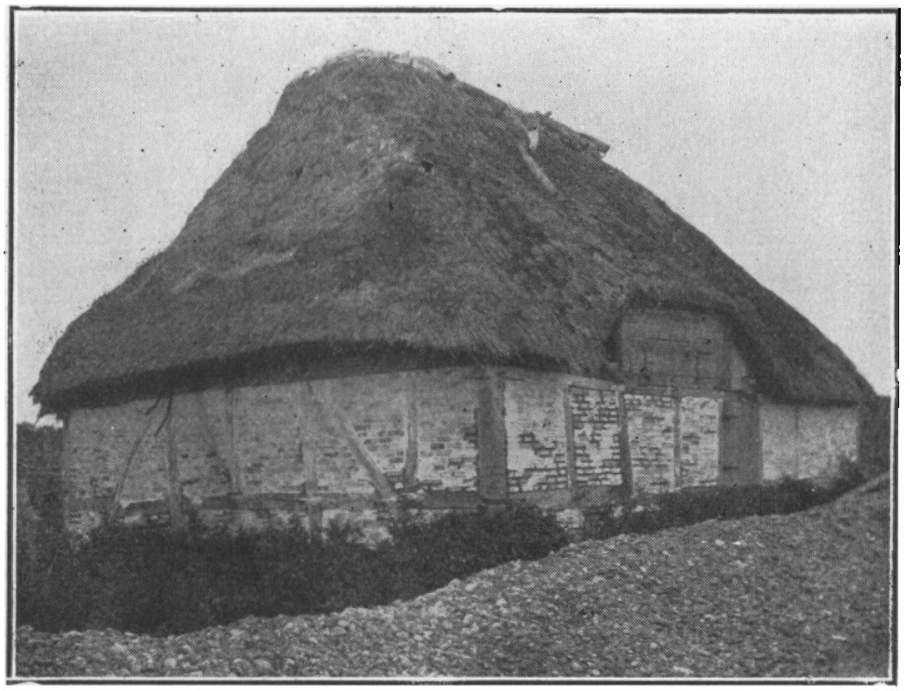

Fig. 23. Braadhus ved Hagenbjerg By. (Forf. fot. 1922).

moderne Skrivebordsstole, kun er de gamle Stole jo utvivlsomt noget skønnere. Paa Væggen mellem Doren ses Uret "e Klok«. Endelig ses paa Billedet, Fig. 22, et Hjørne af Stuen, hvori Bilæggeren er blevet anbragt paa skraa, hvad vel nok er noget usædvanligt. Paa Bilæggeren staar »S tølp e n«, der som oftest var af Messing, hvori man kunde holde Maden varm.

Ligesom man i de senere Tider henlagde Bagningen til et særskilt bygget Bagehus, saaledes henlagde man ogsaa Hortilberedningen til de samme Huse 


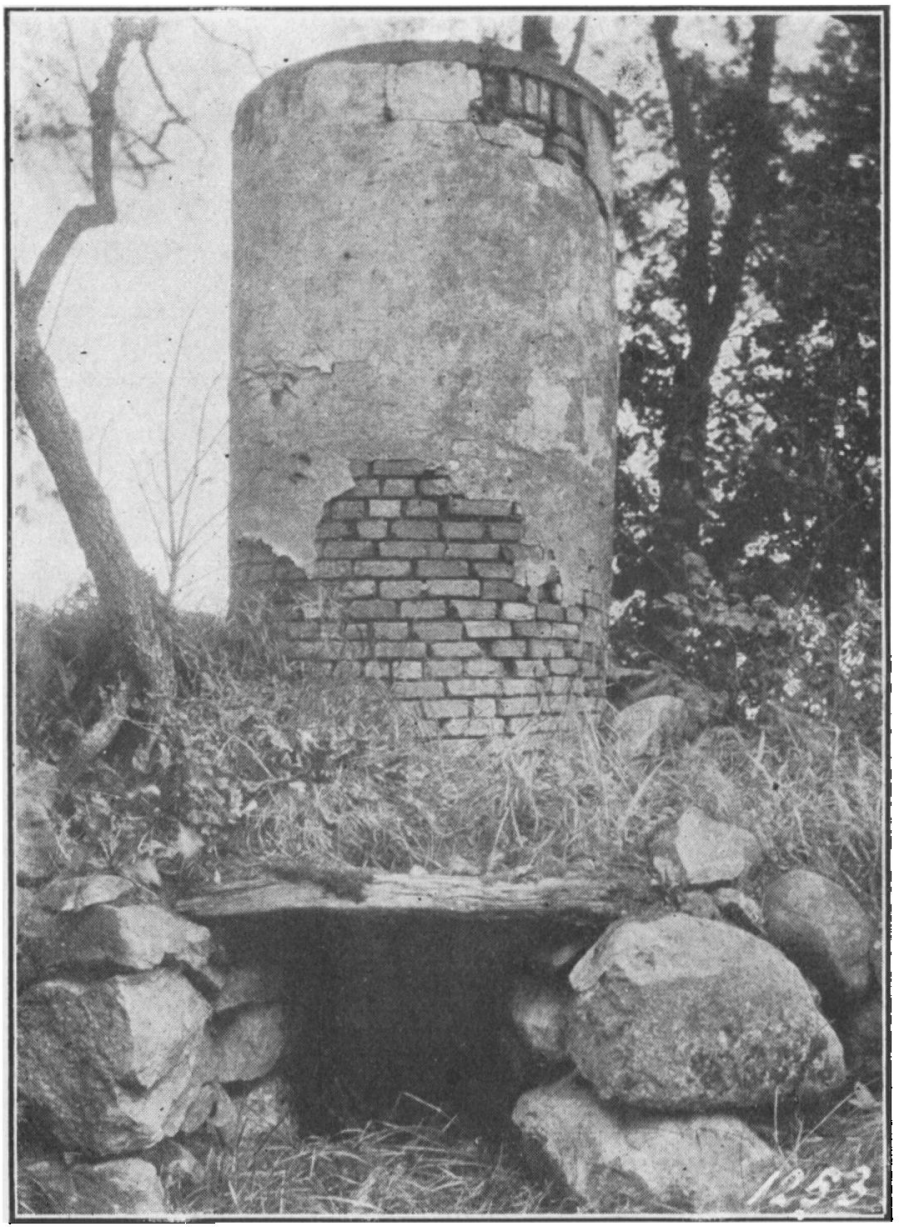

Fig. 24. Braadkul i Horup Overby. (Forf. fot. 1922).

eller opførte lignende Huse, de saakaldte "B ra a dh u se«, som ses paa Billedet, Fig. 23, og som gerne blev bygget et Stykke uden for Byen, af Hensyn til Brandfaren. Huset paa Fig. 23 er fra Hagenbjerg, og havde $i$ ældre Tid haft en Ovn, aldeles lignende en Bagerovn, men Ovnen var i 1922 forsvundet. I Ov- 
nen torrede og ophedede man Horren, inden den blev brudt og videre tilberedt. Man har dog ogsaa i senere Tider haft en helt i det Frie staaende Ovn til dette Brug, den saakaldte "B raadkul", af hvilke der i 1922 endnu fandtes én, vistnok den sidste paa Als, som ses paa Billedet Fig. 24.

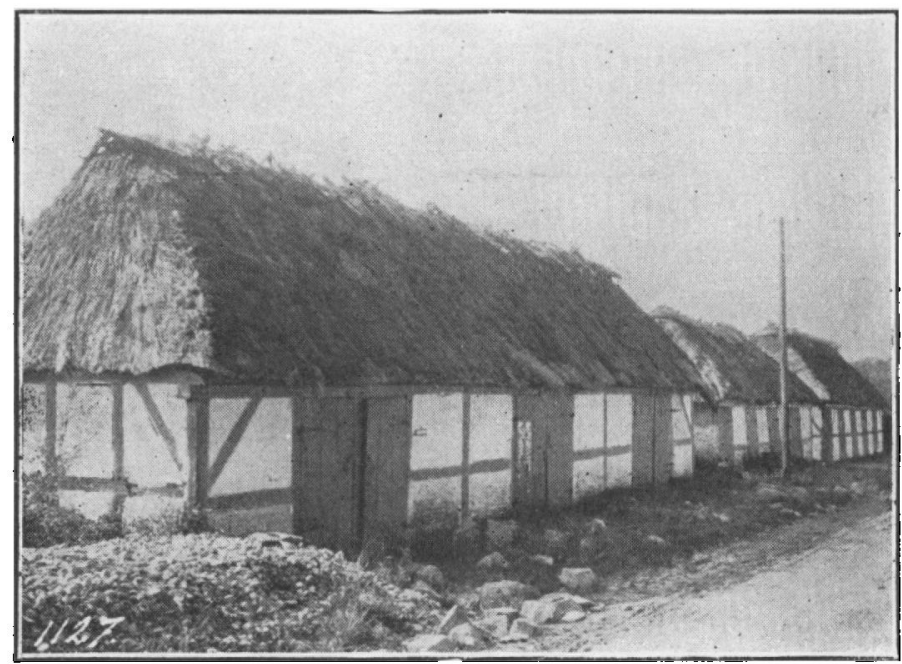

Fig. 25. Kirkestalde ved Notmark Kirke (Forf. fot. 1922).

Den var bygget i et Havegærde i en Gaard i Hørup Overby. Som Regel havde flere Bønder en saadan Ovn fælles. Braadkullen ligner, som det ses, en lille Skorsten og var altid muret af Teglsten. I Rummet forneden fandtes Ildstedet, her indbygget $i$ Havegardet, og i passende Højde over Ilden var anbragt en Jernrist. Herpaa stillede man Hørstænglerne lodret og stak disse ned fra oven. Naturligvis maatte man passe at Ilden ikke var for stærk og at Jernristen ikke blev gloende, da der ellers gik Ild i Hørren, hvad der vistnok ogsaa ofte skete, især naar 
man havde faaet Folk til at passe Ovnen, der var ukyndige $\mathrm{i}$ dennes Behandling.

De Bygninger, som hidtil er nævnt, tilhører jo alle selve Bøndergaardene, og danner ligesom en Ramme om det daglige Liv, der levedes i disse Gaarde. Men der var dog ogsaa andre Bygninger i Landsbyerne, som især var beregnet for Landalmuen, nemlig Skolen og Kirken. Begge disse ligger vel uden for hvad her skal omtales, men til Kirkerne hørte dog nogle Smaabygninger, $K$ irk esta ld e n e, som man vel ikke helt kan fratage en Tilknytning til selve Bøndergaardene, og Billedet, Fig. 25, viser en saadan Række af Stalde ved Notmark Kirke, altsaa ganske enkle smaa Bindingsværkshuse med en Halvport for hver Stald. Den storste Samling af denne Art Bygninger paa Øen findes ved Egen Kirke.

Til en Landsby hører der, som bekendt, ogsaa en Kro, og af disse har der nu ikke været saa faa paa Als. Den smukkeste af disse Jaa i sin Tid i Dyndved, og Fig. 26 viser, hvorledes den saa ud, inden den blev ombygget. Karakteristisk for denne, saavel som for en lignende Kro i Egen, var den store Bindingsværksgavl, som var knægtbygget, saaledes at det ene Stokværk sprang frem over det andet, og Foden i hvert Stokværk hvilede paa Knægte. Man ser, at der er Hejsevark, anbragt i Overgavlen, og i det mellemste Stokværk ser vi Lemmen eller Døren ind til Loftet, hvor man har opbevaret Kornet til Brændevinen, som tillavedes i selve Kroen.

I det foregaaende er det væsentligste om de alsiske Bøndergaarde og deres Indretning blevet omtalt, og vi skal derefter se lidt paa det alsiske Bindingsværk. Naar en Gaard skulde rejses eller byg- 


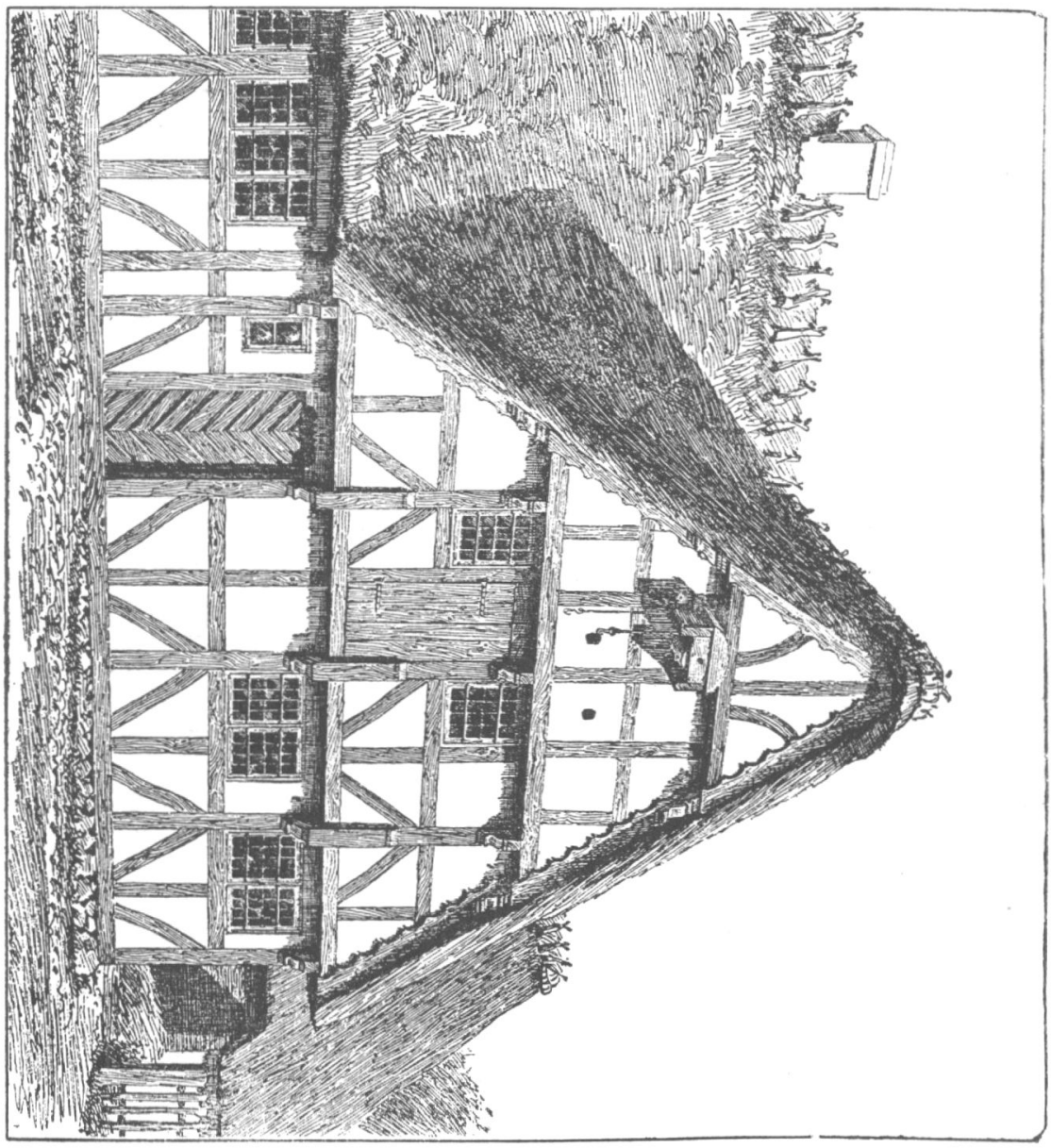

ว net, og tillige naar han skulde begynde. Alle Bysens Mænd gav ham da Tilsagn om Hjælp, og den fastsatte Dag stillede de med hver sit Værktøj og hjalp ham tilrette med "e Timmerværk», der jo er ret 3.8.8. omfattende og fortrinligt gjort $i$ de alsiske Gaarde, og navnlig Laderne med de 3 Tavl i Højden: "Hø jtim meret«, gjorde jo ikke Arbejdet lettere. 
Over "Gr u n d s t e n e n e« lagdes »e L e d e«, Fodtommeret, der findes overalt paa alsiske Bønderbygninger. Heri var indtappet Stolperne, som kaldtes »S t e n d e r", hvorfor Bindingsværket kaldes "S t e nd e rværk«, og foroven er Stolperne tappet i Remmen, hvor de holdes fast med en Nagle ne Potnav l". Mellem Stolperne er "Bindingsstykk e $\mathrm{r}$ e« eller Fyldetømmeret anbragt, der bestaar af de vandret liggende "L o s h o lt e r og de lodrette Smaastykker "B rakker», der er det samme som det norrejydske Dok eller Pebling. Alt er sammentappet, og i Losholttappene findes Nagler, derimod ikke i Brakkenes Tappe. Til yderligere Afstivning anvendes Skraabaand, som i ældre Tider vistnok ogsaa kaldtes "Ramp«- eller "Kropstiver». Ogsaa disse er tappede sammen med det øvrige Tømmer, og her findes altid Nagler i Tappene, hvad der især understreger den konstruktive Betydning, man har tillagt disse Skraastivere. I Indhusene findes de oftest kun i de underste Tavl, men ofte gaar de igennem 2 Tavl og varierer undertiden saaledes, at der opstaar ret ejendommelige og morsomme Figurer i Bindingsværket. De krogede Skraabaand er meget karakteristiske for de alsiske Bygninger, men de genfindes dog ogsaa i de vestfynske Bøndergaarde.

Bjælkerne hviler overalt paa Remmen over Stenderne, og Stendernes Tappe gaar helt gennem Remmene og et Stykke op i Bjælkerne, hvorved disse holdes paa ,Plads. Bjælkernes Ender er for det meste skraat afskaaret udefter oven for Remmen, eller ogsaa skæres de efter det Profil, som Udmuringen har mellem Fem og Tag. Denne Aabning mellem Rem og Tagets Linderkant, "H $\mathrm{H} \mathrm{l}$ def a g e t«, som det og- 
saa kaldes paa Fyn (jydsk Ovs), var i ældre Tid udklinet med Ler, senere lukkedes Aabningen med et Brædt "T a g b ræd $t \in t$ t" og i senere Tider med raa Lersten paa Kant:, "R o l l-S k e g t « udmuret i Ler. Undertiden var Bjælkerne støttede inde i Stuerne af pynteligt udsvejfede Knægte. S p arrerne er altid tappet i Bjælkerne forneden, og sammentappede foroven. De støttes af $\mathrm{H}$ a $\mathrm{n}$ e b a a $\mathrm{n}$, undertiden endog af 2 Hanebaand, og dét underste kaldes da "S $t$ i n dbjælke«. Sparrerne bliver "gabborede" til "e Lat $\mathrm{t}$ er«, Lægterne, og disse, som kun naar fra Spær til Spær, fastgøres med Lagtenagler "T o ll e“. der kun anbringes i Lagtens ene Ende, medens den anden Ende hviler paa den Lægte, der er fastgjort i Nabospæret. I tidligere Tider anvendes altid "S yref «, Halmsimer til at sy Taget med.

Paa Rygningen anbringes "V a a r d r $r$ er«, der svarer til de sjællandske Kragtræer, og om de overalt afskraaede Gavle, der kaldes »E $\mathrm{n}$ d e« - aldrig Gavl - er anbragt den tidligere orntalte Krands, fastgjort med Staver og Pinde i Taget. Ved Strandkanten lagde man Rygningen af Tang, ellers af Halm. De skraa Spær, som anbringes i Hjørnerne mellem de to sammenstødende Tagflader, kaldes "e L o h $r$ $\mathbf{t} \mathbf{r} æ$ æ.

I de klinede og vistnok aldrig med Træ vundne Vægge er indsat "S t a ver«, for det meste af Bøg eller flækket Eg, meget svære Stykker, og herom er slaaet halmblandet Ler. Til Tider vandt man med Halmsimer, for at Leret kunde binde bedre fast ver Staverne. Vægtavlene er almindeligt hvidkalkede, og Stolperne farvedes i aldre Tider med Kalveblod, senere med brunrødt, udrørt i Kærnemælk eller Rug- 
mel, eller sortsværtedes med Kønrøg. Den røde Farve fik man undertiden ved at rive en rød Mursten. I seneste Tider har man malet Stolperne morkegraa.

I de alsiske Bøndergaarde og Huse findes ofte

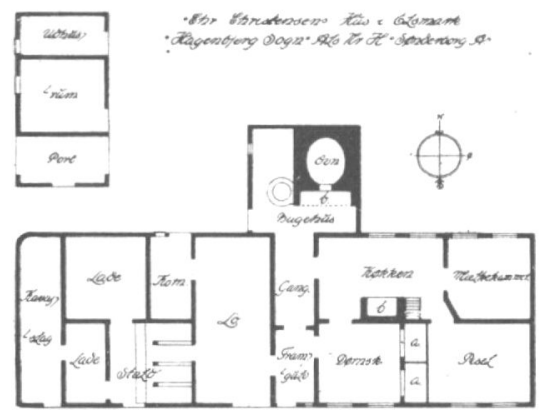

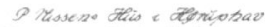

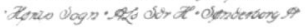

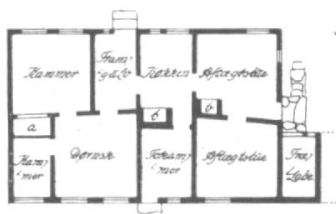

Fig. 27. Grundplaner af Huse i Elsmark og Heruphav. (Opmaall 1923 af Forf.)

blyindfattede Ruder, og Hudernes Antal i Vinduerne er gerne et Kendetegn paa deres Alder, jo flere der er, og jo mindre i Størrelse, desto ældre er de. De ældste Vinduer er $16-30$ rudede, de yngste er 6 rudede. Mange Steder finder naan ogsaa pyntelige Indgangs(løre. I Almindelighed er Dørene for Udhusrummene Halvdøre, og Stenen udfor Indgngsdøren til Framgulvet kaldtes "Dørselu. 
Over Dorene fandtes, som gentagne Gange tidligere er omtalt, Inskriptioner'i Dørstykket. Over Døren paa et Hus i Elstrup stod: Clavs Pettersen. Maria Clavses. Den 14. Avgustus 1777. Solli. Deo. Glorria: Over en Dør i en Gaard paa Elstrup Mark stod: "O Herre Gud dette Hus bevar fra Ilds Nød og anden Farre. - Amen. - Her æeder jeg mit Brød som Gud mig onder«. Endelig skal her tilføjes den alvorsfulde Dør-Inskription, som Professor Mejborg har fundet her ovre: "Memento mori“, ihukom Døden.

Som en Prøve paa alsiske Smaahuse ses paa Billedet, Fig. 27, et mindre Hus paa ca. 6 Tdr. Land fra Elsmark, hvor man genfinder de sædvanlige Træk i Beboelsen: Køkken med vedliggende Mælkekammer mod Nord, Dørnsk med Alkover og Piselen mod Syd. Staldene er dog her adskilte fra Beboelsen ved en Lo, og paa Nordsiden er tilbygget et Korshus, indrettet til Bagehus. - Planen derunder viser et mindre Hus uden Jordbrug fra. Høruphav. Ogsaa her har man en Aftægtsbolig, og det er" saaledes ejendommeligt at se, hvorledes man overalt paa. Øen har tænkt paa den særlige Bolig for de Gamle, et Træk, som man ellers ikke for ofte finder i Landets avrige Gaarde og Huse, men som synes at være ganske almindeligt og typisk for Als.

Det gamle Bindingsværk, som paa Àls har haft et særligt højt Kulturstade, og som viser en overordentlig dygtig og fint udviklet Tømmermandskunst, findes vel endnu i gamle alsiske Bønderbygninger, selv om mange af disse desværre er forsvundet og har maattet give Plads for Nybygninger, der vel nok svarer til moderne Krav, men som sjældent, saaledes som de gamle Bygninger, svarer til det frodige, 
skonne og ejendommelige alsiske Landskab. Det vilde maaske derfor være af Betydning, om man her og der forsøgte at værne om de bedste, og vistnok ikke helt ubrugelige gamle Bygninger paa Als, der til alle Tider vil være et værdifuldt Minde om en gammel og smuk Bolig- og Byggeskik, lige fortrinlig i saavel teknisk som kulturel Henseende. 